\title{
Cloud condensation nuclei properties of South Asian outflow over the northern Indian Ocean during winter
}

\author{
Vijayakumar S. Nair, Venugopalan Nair Jayachandran, Sobhan Kumar Kompalli, Mukunda M. Gogoi, and \\ S. Suresh Babu
}

Space Physics Laboratory, Vikram Sarabhai Space Centre, Thiruvananthapuram, India

Correspondence: Vijayakumar S. Nair (vijayakumarsnair@gmail.com)

Received: 16 September 2019 - Discussion started: 1 October 2019

Revised: 28 January 2020 - Accepted: 5 February 2020 - Published: 16 March 2020

\begin{abstract}
Extensive measurements of cloud condensation nuclei $(\mathrm{CCN})$ and condensation nuclei $(\mathrm{CN})$ concentrations in the South Asian outflow to the northern Indian Ocean were carried out on board an instrumented research vessel, as part of the Integrated Campaign for Aerosols, gases and Radiation Budget (ICARB) during the winter season (JanuaryFebruary 2018). Measurements include a north-south transect across the South Asian plume over the northern Indian Ocean and an east-west transect over the equatorial Indian Ocean $\left(\sim 2^{\circ} S\right)$, which is far away from the continental sources. South Asian outflow over the northern Indian Ocean is characterized by the high values of CCN number concentration $\left(\sim 5000 \mathrm{~cm}^{-3}\right)$, low CCN activation efficiency $(\sim 25 \%)$ and a steep increase in CCN concentration with the increase in supersaturation. In contrast, low CCN concentration $\left(\sim 1000 \mathrm{~cm}^{-3}\right)$ with flat supersaturation spectra was found over the equatorial Indian Ocean. The CCN properties exhibited significant dependence on the geometric mean diameter (GMD) of the aerosol number size distribution, and $\mathrm{CCN}$ activation efficiency decreased to low values $(<20 \%)$ at the time of new-particle formation events over near-coastal and remote oceanic regions. The analysis of the activation efficiencies for the "similar" aerosol size distributions over the northern Indian Ocean indicated the primary role of aerosol number size distribution on $\mathrm{CCN}$ activation efficiency. The dependence of $\mathrm{CCN}$ properties and activation efficiency on size-segregated aerosol number concentration, especially during the ultrafine $(<100 \mathrm{~nm})$ particle events, is investigated in detail for the first time over the region.
\end{abstract}

\section{Introduction}

Aerosol-climate interaction is one of the major uncertain components of the Earth-atmosphere system, which includes several pathways like aerosol-radiation (scattering and absorption of solar radiation), aerosol-cloud (modification of cloud properties due to aerosols), aerosol-cryosphere (snow albedo reduction due to aerosol deposition) and aerosolbiosphere interactions having significant radiative forcing (IPCC, 2013; Rosenfeld et al., 2014; Li et al., 2016). IPCC (2013) has estimated the global mean radiative forcing due to aerosol-radiation and aerosol-cloud interaction to be $-0.9(-1.9$ to -0.1$) \mathrm{W} \mathrm{m}^{-2}$, which compensates for nearly $30 \%$ of the warming due to well-mixed greenhouse gases. The fundamental parameter relevant for understanding the aerosol-cloud interaction is the cloud condensation nuclei $(\mathrm{CCN})$, which are those aerosols that become activated at supersaturations pertinent to atmospheric conditions (Rosenfeld et al., 2014). Hence, the large uncertainty in the estimates of aerosol-cloud interaction points to the necessity of dedicated field campaigns and modelling efforts to improve the level of scientific understanding on $\mathrm{CCN}$ activation and to accurately quantify the change in microphysical properties of clouds due to anthropogenic aerosols (Rosenfeld et al., 2014). Regional meteorology also plays a major role in the aerosol-cloud interaction and the effect of aerosols on clouds varies with meteorological regimes (Reutter et al., 2009; Kerminen et al., 2012; Schmale et al., 2018). Since the oceans cover about $70 \%$ of the Earth surface and the low-level marine clouds (stratus and stratocumulus) are highly sensitive to aerosol perturbations (Rosenfeld et al., 2014), understanding the $\mathrm{CCN}$ properties and their dependence on the physicochemical properties of aerosols is crucial to understanding 
the aerosol-cloud interactions over the oceanic regions lying downwind of continental outflow (Furutani et al., 2008; Kim et al., 2014; Snider and Brenguier, 2000).

The south Asian region, especially northern India, experiences high aerosol loading during the winter season (Nair et al., 2007; Bharali et al., 2019). These aerosols are mostly confined to within the atmospheric boundary layer and have significant implications for air quality, visibility, human health and the radiation budget (Lelieveld et al., 2001; Bharali et al., 2019). Due to the favourable prevailing wind system, these continental aerosols are being transported over the northern Indian Ocean (Arabian Sea and Bay of Bengal), and the effects of these anthropogenic aerosols on regional climate have been the major scientific theme for the several field campaigns and modelling studies carried out during the last 2 decades (Moorthy et al., 2009; Ramanathan et al., 2001; Lelieveld et al., 2001; Ackerman et al., 2000; Nair et al., 2013). South Asian outflow characterized during the Indian Ocean Experiment (INDOEX) revealed that high concentrations of black carbon (BC) and organic carbon (OC) aerosols are emitted from biomass and fossil fuel burning over South Asia and get transported to the Indian Ocean during winter (Mayol-Bracero et al., 2002). Several studies have shown that the transport of anthropogenic aerosols, especially carbonaceous aerosols, to the marine atmosphere perturbs the regional radiation balance through aerosol-radiation (Ramanathan et al., 2001; Moorthy et al., 2009) and aerosol-cloud interactions (Ackerman et al., 2000; Chylek et al., 2006; Hudson and Yum, 2002). The INDOEX observations indicated that $\mathrm{CCN}$ characteristics of the northern Indian Ocean are impacted by the outflow of South Asian aerosols as seen from the widespread nature of the high CCN number concentrations over the region (Cantrell et al., 2000, 2001). Following INDOEX, even though there were several field experiments like ICARB-2006, ARMEX (Arabian Sea Monsoon Experiment) and ICARB-2009 to characterize the aerosol properties, simultaneous measurements of the $\mathrm{CCN}$ and aerosol properties have not been attempted in the South Asian outflow region for the last 2 decades.

The CCN properties exhibit considerable spatial and temporal heterogeneities similar to the extrinsic properties of aerosols (Andreae, 2009; Jefferson, 2010). Hence, aerosol$\mathrm{CCN}$ studies for distinct aerosol types (like polluted, marine, biogenic and dust) assume importance (Schmale et al., 2018). Even though several studies have addressed the activation properties of aerosols using extensive measurements over distinct aerosol environments (Furutani et al., 2008; Rose et al., 2011; Kerminen et al., 2012; Pöhlker et al., 2016; Schmale et al., 2018), studies are limited over South Asia and its outflow regions. Size-segregated measurements of CCN concentration along with physical and chemical properties of aerosols are essential to unravel the complex dependence of size and chemistry of aerosols on CCN activation (Dusek et al., 2006a; Pöhlker et al., 2016; Rose et al., 2011; Furutani et al., 2008; Hudson, 2007), which is essential for the bet- ter prediction of $\mathrm{CCN}$ concentration, and thus to reduce climate forcing uncertainty due to aerosol-cloud interactions. Studies on the relative importance of aerosol size distribution and chemical composition (mixing state) on the CCN properties are rather limited over the Indian subcontinent, except for a few studies (Jayachandran et al., 2018, references are therein). At a microscopic level, a fraction of the total aerosols become activated as $\mathrm{CCN}$, which depends primarily on the size, followed by chemical composition and mixing state of the aerosol system (Jimenez et al., 2009; Dusek et al., 2006a; Kerminen et al., 2012; Rose et al., 2011). There exists a substantial uncertainty in the activation properties of particles, especially the contribution of ultrafine particles (size below $100 \mathrm{~nm}$ ) and new-particle formation events to the global CCN concentration (Pierce and Adams, 2007; Merikanto et al., 2009). Further, the role of higher levels of ultrafine aerosols in CCN number concentration and activation efficiency is not investigated over the northern Indian Ocean, especially when the continental outflow dominates the marine aerosol system.

In this study, we present the results from the dedicated shipborne measurements onboard the oceanographic research vessel (ORV) Sagar Kanya (SK) during winter 2018 (hereafter ICARB-2018) carried out as part of Integrated Campaign for Aerosols gases and Radiation Budget (ICARB) experiment with a broad objective to characterize the South Asian outflow. The measurements were carried out within the continental outflow and remote oceanic regions far away from South Asia. The present study focusses on wintertime measurements of the $\mathrm{CCN}$ concentrations at different supersaturations, along with simultaneous measurements of the aerosol properties when the entire northern Indian Ocean was under the influence of continental outflow from South Asia. The northern Indian Ocean is an ideal and unique region to study the role of anthropogenic aerosols in CCN activation, where aged continental plume having a high concentration of carbonaceous aerosols and volatile vapours mix with marine aerosols during the northern hemispheric winter (Mayol-Bracero et al., 2002; Nair et al., 2007, 2013). This paper discusses the general characteristics of the CCN concentrations, activation properties and their association with aerosol number size distribution at different regions of the South Asian outflow. The relative role of aerosol number size distribution on the variability of $\mathrm{CCN}$ activation and the contribution of ultrafine particles to the $\mathrm{CCN}$ concentration will be discussed in detail.

\section{Campaign, instruments and general meteorology}

During the winter months, the prevailing large-scale circulation over South Asia is favourable for the transport of anthropogenic aerosols to the Arabian Sea and Bay of Bengal (Ramanathan et al., 2001; Nair et al., 2007; Moorthy et al., 2009). The spatial extent of the aerosol transport to 
the Indian Ocean is qualitatively depicted by the climatological (2002-2017) mean aerosol optical depth (AOD) derived from MODIS (Moderate Resolution Imaging Spectroradiometer) observations over the northern Indian Ocean (contours in Fig. 1). High aerosol loading (AOD > 0.3) is observed over the northern Bay of Bengal and the southeastern Arabian Sea during winter. The ICARB-2018 measurements were planned to be carried out within this plume area over the southeastern Arabian Sea and the regions far away from the continental outflow. The ship cruise on board ORV Sagar Kanya started from Goa $\left(15^{\circ} \mathrm{N}, 73.8^{\circ} \mathrm{E}\right)$ on 16 January 2018 and ended at Tuticorin $\left(8.8^{\circ} \mathrm{N}, 78.2^{\circ} \mathrm{E}\right)$ on 13 February 2018. The cruise track is shown in Fig. 1. The ICARB-2018 cruise experiment mainly has three phases: (i) latitudinal (16-22 January 2018), (ii) longitudinal (2331 January 2019) and (iii) return (1-13 February 2019) phases. Aerosol properties reported during each of the measurement phases have a strong association with large-scale meteorology, as reported in the earlier field experiments (Lelieveld et al., 2001; Ramanathan et al., 2001; Nair et al., 2013). Depending on the origin of air masses, measurements made during ICARB-2018 are classified into three different groups (Fig. 1). The first phase of the cruise over the southeastern Arabian Sea (SEAS) is divided into "SEAS1" and "SEAS2" regions where the former is influenced by the air masses from peninsular India and the latter by air masses from the Bay of Bengal. The SEAS1 region has proximity to coastal India, while SEAS2 is relatively far away from the mainland. The second phase of the cruise over the remote equatorial Indian Ocean (EIO), where the continental influence is rather less compared to SEAS1 and SEAS2, is regarded as the third group. Mostly calm and clear-sky conditions prevailed during the campaign except for a few rainfall spells on 4, 6 and 7 February 2018 when the ship was sailing over the southeastern Arabian Sea $\left(4^{\circ} \mathrm{N}, 67.2^{\circ} \mathrm{E}\right)$. These widespread rainfall events associated with the western disturbances are also observed over the peninsular and western part of the Indian subcontinent during this period. Due to these weather events, we have not considered the data collected during the return phase (phase 3 ) in this study. The mean values of air temperature and relative humidity during ICARB2018 from the automatic weather station observations were $28.0 \pm 0.8^{\circ} \mathrm{C}$ and $74 \pm 5 \%$ respectively.

Aerosol instruments were installed in a customized laboratory on the top deck ( $\sim 15 \mathrm{~m}$ above sea level) of the ship. The instruments aspirated ambient air from a manifold sampling inlet having a $10 \mu \mathrm{m}$ size cut-off at a flow rate of $16.6 \mathrm{~L} \mathrm{~min}^{-1}$. The flow rate was frequently monitored and maintained using a flow controller and an external pump. To avoid the contamination of the ship's exhaust with the aerosol measurements, the bow of the ship was mostly aligned with the upwind direction, and those measurements when the wind was blowing from the rear side of the ship were excluded. All the measurements were averaged hourly for uniformity, after applying the necessary quality

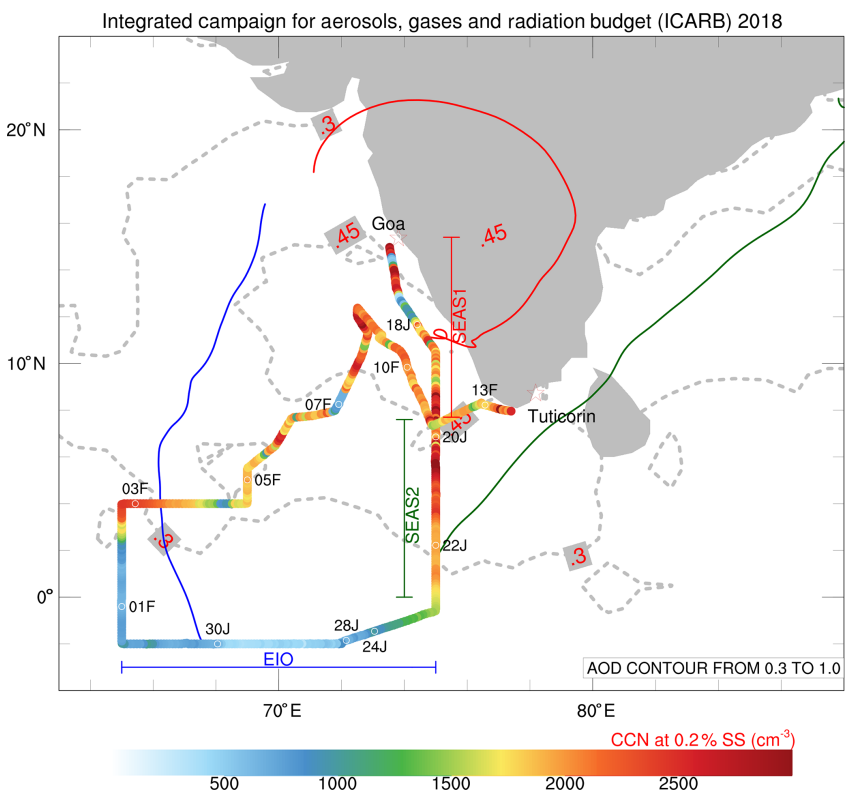

Figure 1. The cruise track of ICARB 2018 over the northern Indian Ocean. The colour of the cruise track indicates the CCN number concentration $\left(\mathrm{cm}^{-3}\right)$ at $0.2 \%$ supersaturation (SS). CCN characteristics at three distinct regions marked as SEAS1, SEAS2 and EIO are discussed in this study. Noontime ship location is marked by dates suffixed with $\mathrm{J}$ and F, where "J" for January and "F" for February. Grey coloured contours indicate the climatological mean values of aerosol optical depth at $550 \mathrm{~nm}$ derived from the MODIS satellite for the winter season. Typical air mass back trajectories arriving at the ship location on 18, 22 and 30 January 2018 representing the SEAS1 (red colour), SEAS2 (green colour) and EIO (blue colour) region respectively, estimated using HYSPLIT model are shown as solid lines.

checks and instrument-specific data correction procedures, and then geolocated using the time-stamped position information available from the GPS receiver installed onboard. The simultaneous measurements of CCN number concentration using a $\mathrm{CCN}$ counter and aerosol number size distribution from a scanning mobility particle sizer (SMPS) form the primary dataset for this study.

$\mathrm{CCN}$ number concentration measurements at different supersaturations ranging from $0.2 \%$ to $1.0 \%$ were carried out using a single-column continuous-flow CCN counter (model: CCN-100; make: DMT) at a time resolution of $1 \mathrm{~Hz}$. The difference in the radial diffusion rate of heat and water vapour is used to develop specific supersaturations along the centre line of the instrument column, depending on the sheath-tosample flow rate and the temperature gradient along the column (Roberts and Nenes, 2005). The aerosols are introduced into the centre line of the filtered, humidified sheath flow. The aerosols of a size greater than the critical diameter at the set supersaturation will grow as $\mathrm{CCN}$, which are counted further by an optical particle counter with a diode laser source at $660 \mathrm{~nm}$ wavelength. In the present study, a constant flow rate 
of $0.5 \mathrm{~L} \mathrm{~min}^{-1}$ and a steady sheath to sample the flow ratio of $10: 1$ was maintained throughout the campaign. The duration of each cycle of $\mathrm{CCN}$ measurements $(0.2 \%$ to $1.0 \%$ supersaturation) spanned $30 \mathrm{~min}$ (Jayachandran et al., 2017, 2018). Considering the instability inside the column during the supersaturation changes, more time is allocated to the lowest supersaturation $(0.2 \%)$ and the first 2 min of data of each supersaturation are excluded from the analysis.

Aerosol number size distribution measurements were carried out using a scanning mobility particle sizer (make: TSI), which measured the size-segregated number concentration of particles from $\sim 9$ to $420 \mathrm{~nm}$. The SMPS consists of a differential mobility analyser (DMA, model: TSI 3081) and a water-based condensation particle counter (CPC, model: TSI 3786). The particles segregated according to their electrical mobility by the DMA are allowed to grow in the condensation chamber of the CPC to the optically detectable size range. These particles are counted by using an optical particle counter (Wang and Flagan, 1990). All the instruments were calibrated prior to the campaign following the standard protocols.

\section{Results and discussion}

\subsection{CCN number concentrations}

The number concentration of $\mathrm{CCN}$ at $0.2 \%$ supersaturation, which represents the concentration of aerosols that are hygroscopic and sufficiently large (size $>100 \mathrm{~nm}$ ) to become activated at low $(0.2 \%)$ supersaturations, is shown along the cruise track in Fig. 1. High concentrations of CCN $(\sim$ $2000 \mathrm{~cm}^{-3}$ ) are observed in the plume area (SEAS1), and lower CCN concentrations $\left(<500 \mathrm{~cm}^{-3}\right)$ are seen over the southwest part of the cruise track $\left(\sim 2^{\circ} \mathrm{S}, 65\right.$ to $\left.72^{\circ} \mathrm{E}\right)$. The low values observed during the return phase of the cruise are attributed to the effective wet scavenging of aerosols due to thunderstorms experienced on 4, 6 and 7 February 2018. The SEAS2 region, which is mostly affected by the advection from the Bay of Bengal region (lying downwind of the Indo-Gangetic Plain; Fig. 1), also showed high $\mathrm{CCN}$ concentrations of up to $2500 \mathrm{~cm}^{-3}$ indicating the widespread influence of South Asian outflow. The latitudinal gradient of $\mathrm{CCN}$ at different supersaturations from $15^{\circ} \mathrm{N}$ to the Equator, between the longitudes 74 to $75^{\circ} \mathrm{E}$, shows distinctly different patterns for the $\mathrm{CCN}$ concentrations at low $(0.2 \%)$ and high $(1.0 \%)$ supersaturations as shown in Fig. 2. At $0.2 \%$ supersaturation, $\mathrm{CCN}$ values observed over SEAS1 $\left(1683 \pm 435 \mathrm{~cm}^{-3}\right)$ are lower or comparable to that over SEAS2 $\left(1868 \pm 276 \mathrm{~cm}^{-3}\right)$. This is contrary to the CCN values at $1.0 \%$ supersaturation, where $\mathrm{CCN}$ values are 2fold higher over SEAS1 $\left(5954 \pm 1493 \mathrm{~cm}^{-3}\right)$ compared to SEAS2 $\left(2513 \pm 668 \mathrm{~cm}^{-3}\right)$. The systematic decrease in the $\mathrm{CCN}$ number concentration with latitude is clearly seen below the southern tip $\left(<8^{\circ} \mathrm{N}\right)$ of peninsular India, whereas

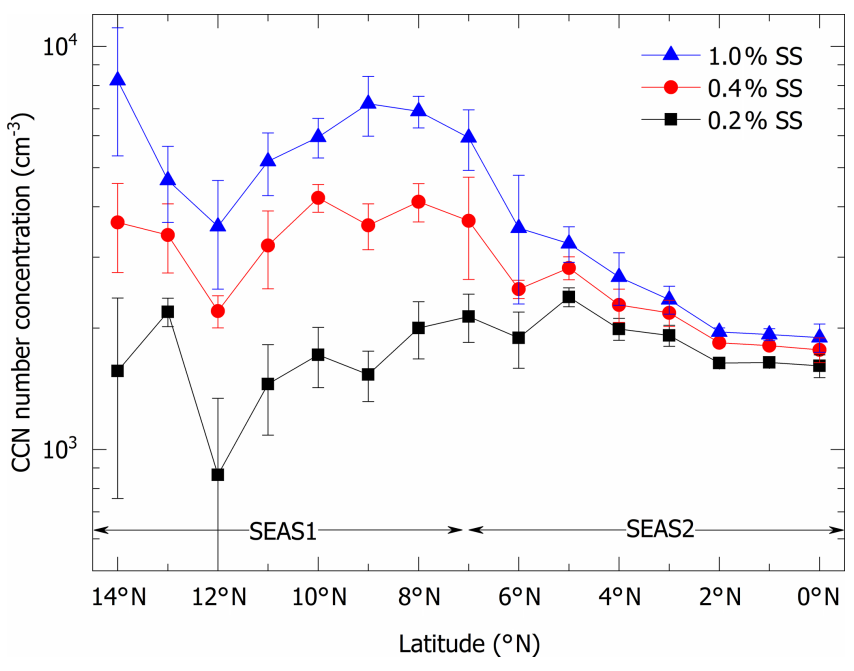

Figure 2. Latitudinal variation in the $\mathrm{CCN}$ number concentration at $0.2 \%, 0.4 \%$ and $1.0 \%$ supersaturations (SS) over the southeastern Arabian Sea (SEAS). The vertical bars on each data point indicate the standard deviation of the measurements. The SEAS region is further divided into SEAS1 and SEAS2 based on the origin of air mass back trajectories and proximity to the mainland.

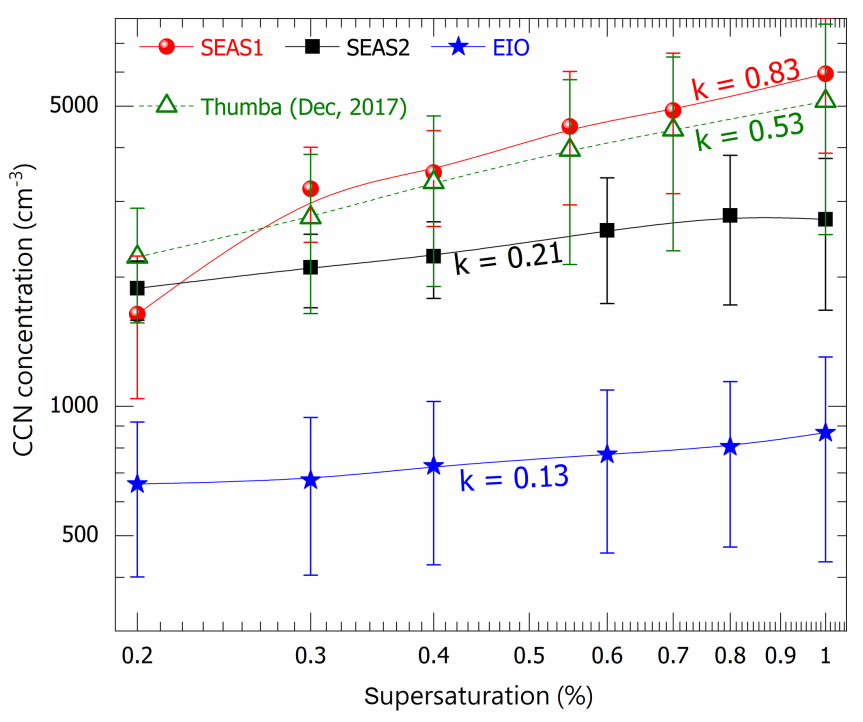

Figure 3. Mean CCN number concentration with the standard deviation at different supersaturations over the northern Indian Ocean (SEAS1, SEAS2 and EIO) during ICARB-2018. The CCN spectra measured at a coastal station, Thumba, are also shown in the figure for comparison. The graph is shown on a log-log scale.

measurements above $8^{\circ} \mathrm{N}$ are modulated by the heterogeneous sources located along the west coast of India. The CCN concentration at $1.0 \%$ supersaturation was 5- to 7fold higher than that at $0.2 \%$ supersaturation over SEAS1, whereas the rate of change in CCN concentration with supersaturation is insignificant over SEAS2. 
The regional variation in the mean $\mathrm{CCN}$ concentration with respect to supersaturation (commonly called CCN spectra) over SEAS1, SEAS2 and EIO is shown in Fig. 3. The mean CCN spectra observed during December 2017 at Thumba $\left(8.5^{\circ} \mathrm{N}, 77^{\circ} \mathrm{E}\right.$; Jayachandran et al., 2018), which is located on the west coast of peninsular India (close to SEAS1) and experienced the same synoptic conditions as that during the ICARB-2018 campaign, are also shown in the figure for comparison. In general, the $\mathrm{CCN}$ concentration will be higher or remain constant as supersaturation increases. As the set supersaturation inside the instrument increases, more and more particles will become activated since the supersaturation inside the instrument column is higher than the minimum supersaturation (called critical supersaturation) required for the particles to become activated. Hence $\mathrm{CCN}$ at higher supersaturation are cumulative, and all particles with critical supersaturation lower than the set supersaturation are activated as $\mathrm{CCN}$. This variation in $\mathrm{CCN}$ with supersaturation is parameterized using the Twomey empirical relationship, $N_{\mathrm{CCN}}=C \mathrm{SS}^{k}$, where SS is supersaturation and $k$ is the Twomey exponent, which is also mentioned in the figure. Twomey's exponent $(k)$ indicates the qualitative information on the CCN active aerosol size distribution, with high $k$ values implying the dominance of ultrafinemode aerosols and low $k$ values indicating the fine-mode $(>100 \mathrm{~nm})$ aerosol dominance in the measured number size distribution (Fang et al., 2016; Jayachandran et al., 2017; Gunthe et al., 2009). In this study, $k$ values are estimated in the supersaturation range from $0.2 \%$ to $1.0 \%$. As shown in Fig. 2, the CCN concentration measured in the South Asian outflow is very sensitive to the supersaturation over SEAS1 (coastal regions adjoining India), whereas CCN concentration is less dependent on supersaturation over the regions far away from the continental sources (SEAS2 and EIO). The higher $(0.83 \pm 0.22)$ value of Twomey's exponent $(k)$ over SEAS1 (steep CCN spectra) is attributed to the dominance of ultrafine-mode aerosols (or somewhat hydrophobic aerosols) in the continental outflow. The lower $k$ values of $0.21 \pm 0.19$ and $0.13 \pm 0.11$ estimated for SEAS2 and EIO respectively suggested larger particle dominance due to the extended transit of aerosols over the oceanic regions leading to enhanced sizes.

It would be interesting to compare the present values of $\mathrm{CCN}$ with the previous observations, which are rather scarcely reported over the oceanic regions surrounding South Asia. Based on the shipborne measurements during INDOEX, Cantrell et al. (2000) reported the CCN concentration of 1000 to $2500 \mathrm{~cm}^{-3}$ (at $0.5 \%$ supersaturation) over 10 to $15^{\circ} \mathrm{N}$. Similarly, airborne measurements on board a research flight (NCAR C-130) during INDOEX reported the values of $\mathrm{CCN}$ at $1.0 \%$ supersaturation as $\sim 1190 \mathrm{~cm}^{-3}$ for polluted air masses and less than $176 \mathrm{~cm}^{-3}$ for clean marine conditions over the southern Indian Ocean (Hudson and Yum, 2002). The CCN values over the SEAS1 region during ICARB-2018 are (i) higher than the CCN values re- ported during INDOEX, (ii) comparable to the values at the coastal site (Thumba) in southern peninsular India and (iii) less than the values reported from polluted continental locations in the Indo-Gangetic Plain (Jayachandran et al., 2020). The CCN values observed over SEAS are mostly lower or comparable to the values over polluted continental sites $\left(2900 \pm 2800 \mathrm{~cm}^{-3}\right.$ at $0.4 \%$ supersaturation) as reported by Andreae (2009) based on the compilation of CCN observations carried out worldwide. Interestingly, the $\mathrm{CCN}$ values over EIO (which is the relatively remote oceanic region) during ICARB-2018 are almost 7-fold higher than the clean marine $\mathrm{CCN}$ values $\left(107 \pm 56 \mathrm{~cm}^{-3}\right)$ and lower than the polluted marine conditions $\left(1060 \pm 400 \mathrm{~cm}^{-3}\right)$ reported by Andreae (2009). Cantrell et al. (2001) also reported high CCN concentrations (in the range of 300 to $1000 \mathrm{~cm}^{-3}$ ) at $0.3 \%$ supersaturation over Kaashidhoo climate observatory over the equatorial Indian Ocean during February-March 1999. The higher concentration of $\mathrm{CCN}$ at the Equator and further south of it clearly indicated the widespread influence of continental outflow over this region (Ramanathan et al., 2001).

In general, as we move away from the continental sources, aerosol abundance (AOD, black carbon and total mass concentration) decrease toward the open ocean as reported by several studies over the northern Indian Ocean (Ramanathan et al., 2001; Moorthy et al., 2009; Hudson and Yum, 2002). Similarly, Chylek et al. (2006) have reported a latitudinal decrease in the $\mathrm{CCN}$ concentration at $1 \%$ supersaturation from $1850 \mathrm{~cm}^{-3}$ at $4^{\circ} \mathrm{N}$ to $700 \mathrm{~cm}^{-3}$ at $0^{\circ} \mathrm{N}$ over the Indian Ocean during the INDOEX campaign. Hudson and Yum (2002) reported that the influence of pollution outflow from South Asia to the Indian Ocean ceased at $5^{\circ} \mathrm{S}$ due to the Intertropical Convergence Zone. Over the same latitudinal sector, the rate of decrease in $\mathrm{CCN}$ concentration with latitude was lower during ICARB experiment (1.4 times) compared to the INDOEX values, which further highlighted the persistent and widespread impact of continental outflow over the northern Indian Ocean during ICARB-2018. Besides, CCN variation with supersaturation also depicted a latitudinal gradient with high $k$ values over SEAS1 and low values over EIO. It is interesting to note that, irrespective of the large decrease in aerosol loading and change in aerosol microphysical properties over the region, the $\mathrm{CCN}$ concentrations at $0.2 \%$ are comparable at all locations (SEAS1, SEAS2 and Thumba) except over EIO (Fig. 3). The high $k$ values are observed at the coastal site, Thumba (Jayachandran et al., 2018) and measurements from Kaashidhoo Climate Observatory $\left(4.97^{\circ} \mathrm{N}\right.$, $73.5^{\circ}$ E) during INDOEX (Cantrell et al., 2001). Similar to SEAS1, an average $k$ value of 0.8 was reported over the northeast Atlantic by Snider and Brenguier (2000) during the ACE2 campaign. Schmale et al. (2018) also reported a similar finding based on the data collected from several distinct locations in Europe. The low $k$ values observed over the SEAS2 and EIO also could be due to the cloud processing of maritime clouds (Noble and Hudson, 2019; Hudson et al., 2015). Since the $k$ value of the CCN spectrum de- 
pends highly on the dominance of the ultrafine particles in the aerosol size distribution and hygroscopicity of the aerosol system, the $k$ values estimated from the CCN measurements for a short range of supersaturations should be interpreted carefully. It should be noted that carbonaceous particles and newly formed ultrafine particles have a low contribution to the $\mathrm{CCN}$ concentration and require extremely high supersaturation conditions for the $\mathrm{CCN}$ activation (Dusek et al., 2006b; Pierce and Adam, 2007).

\subsection{CCN activation efficiency and geometric mean diameter}

The fraction of total aerosol concentration $(\mathrm{CN})$ that can act as $\mathrm{CCN}$ at a specific supersaturation $(\mathrm{CCN}(\mathrm{SS}) / \mathrm{CN})$ is termed $\mathrm{CCN}$ activation fraction or activation efficiency, which is governed mainly by the number size distribution and composition of the aerosol system (Schmale et al., 2018; Dusek et al., 2006a). The scatter plot between the $\mathrm{CN}$ and CCN over SEAS1, SEAS2 and EIO is shown in Fig. 4a, and the colour scale indicates a geometric mean diameter (GMD) corresponding to the composite aerosol number size distribution. $\mathrm{CCN}$ being a specific subset of $\mathrm{CN}$, the $\mathrm{CCN}$ concentrations increased with increasing total aerosol concentrations during most of the observations. Regression analysis of $\mathrm{CN}$ and $\mathrm{CCN}$ at $0.4 \%$ (slope $\sim 0.2$ and $R^{2} \sim 0.45$ ) and $1.0 \%$ (slope $\sim 0.29$ and $R^{2} \sim 0.44$ ) supersaturations has a poor association during the entire campaign period. This is in contrast to the earlier observations (Gunthe et al., 2009; Jayachandran et al., 2018), where the association between $\mathrm{CN}$ and $\mathrm{CCN}$ increased with supersaturation. When the $\mathrm{CN}$ concentration was very high and ultrafine-mode aerosols contributed significantly to the $\mathrm{CN}$ concentrations, as evident from the lower values of the GMD of the aerosol size distribution (Fig. 4a, colour scale), a weak association between $\mathrm{CCN}$ and $\mathrm{CN}$ was observed. For GMD values greater than $100 \mathrm{~nm}, \mathrm{CCN}$ and $\mathrm{CN}$ followed an excellent relationship with $R^{2} \sim 0.99$ and mean activation efficiency of $69 \pm 10 \%$ over all the regions (SEAS1, SEAS2 and EIO). This highlighted that most of the particles in this size range become activated as $\mathrm{CCN}$ irrespective of the regional heterogeneities in the aerosol composition. As aerosol system having a GMD of less than $60 \mathrm{~nm}$ (when ultrafine particles dominate the aerosol size distribution) has deviated significantly from the regression line. This implies that the abundance of ultrafine particles has a direct impact on activation efficiency, since most of these particles may not become activated at $0.4 \%$ and $1.0 \%$ supersaturation levels (Pierce and Adam, 2007).

The influence of the GMD on the $\mathrm{CN}-\mathrm{CCN}$ association is further investigated using the regression analysis between the observed $\mathrm{CCN}$ at $0.4 \%$ supersaturation with the product of CN and GMD (CN - GMD). The coefficient of determination $\left(R^{2}\right)$ had improved from 0.44 to 0.84 when $\mathrm{CN}$ is multiplied with the GMD. The CCN concentration is estimated from the empirical relationship between the $\mathrm{CN}$ and
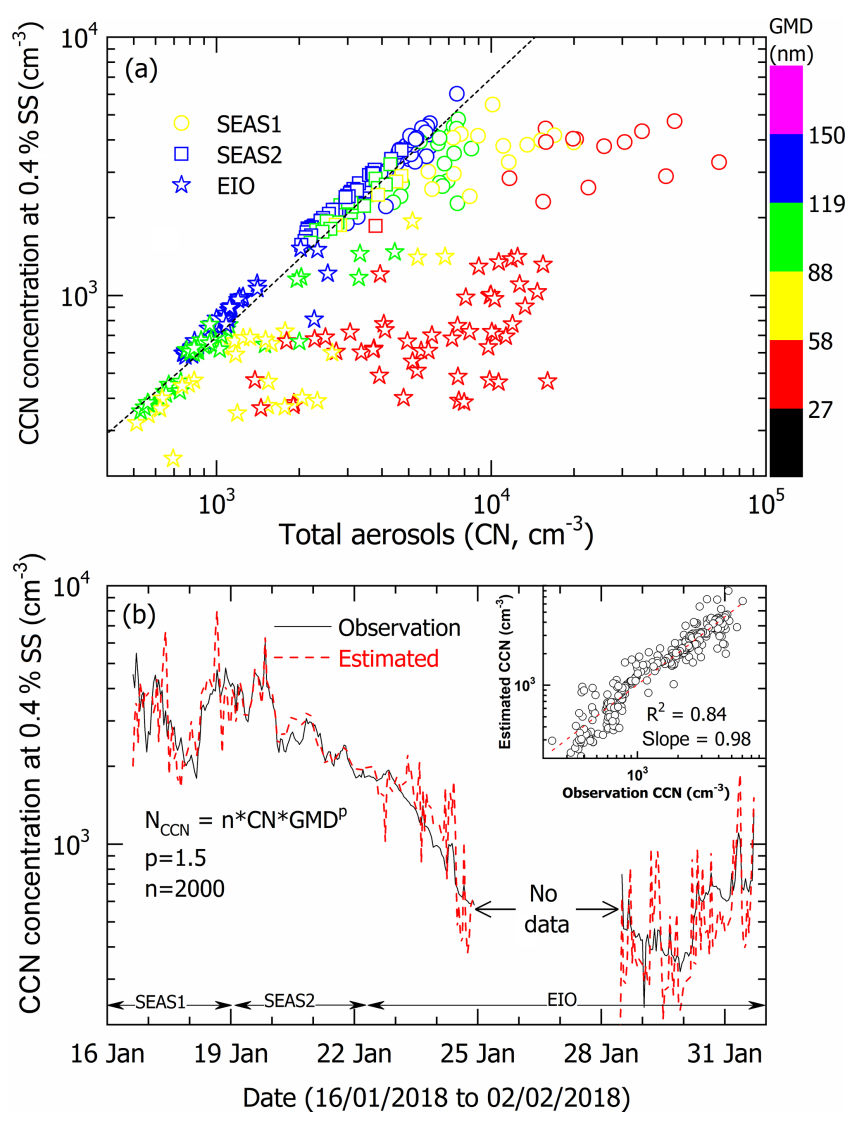

Figure 4. (a) Scatter plot between total aerosol (CN) and $\mathrm{CCN}$ at $0.4 \%$ supersaturation over SEAS1, SEAS2 and EIO. The colour shows the geometric mean diameter (GMD) of the aerosol size distribution. Regression fit for a GMD greater than $100 \mathrm{~nm}$ is shown as a black dotted line. (b) Temporal variation in $\mathrm{CCN}$ concentration at $0.4 \%$ supersaturation (SS) measured using a CCN counter and estimated using the empirical relationship between total aerosol number concentration and geometric mean diameter. The " $p$ " and " $n$ " are empirical constants estimated using the regression technique. The scatter plot of measured and estimated CCN concentration is shown inset.

GMD $\left(\mathrm{CCN}_{\mathrm{est}}=n \cdot \mathrm{CN} \cdot \mathrm{GMD}\right.$, where $n$ is a constant $)$, which showed an excellent association with the measured CCN concentration (at $0.4 \%$ supersaturation). The regression coefficient between measured and estimated $\mathrm{CCN}$ further increased to 0.94 for a power law, $\mathrm{CCN}_{\mathrm{est}}=n \cdot \mathrm{CN} \cdot \mathrm{GMD}^{p}$, where $p(1.5)$ and $n$ (2000) are constants estimated iteratively for the highest value of $R^{2}$. The temporal variation and scatter plot of measured and estimated CCN concentrations at $0.4 \%$ supersaturation are shown in Fig. 4b. By accounting for the effect of the GMD on CCN concentration, this analysis demonstrated the primary role of aerosol number size distribution on CCN activation. Since the ultrafine-mode aerosols have lesser hygroscopicity compared to the finemode (> $1 \mu \mathrm{m}$ ) aerosols (Pöhlker et al., 2016; Gunthe et al., 2009; Pierce and Adams, 2007; Rose et al., 2011), the empir- 
ically estimated $\mathrm{CCN}$ number concentration is overestimated during the periods of ultrafine-particle dominance in the size distribution. The low activation efficiencies during the newparticle formation events and for the higher abundance of ultrafine-mode aerosols have been reported in the literature (Pöhlker et al., 2016). The present analysis of estimating the $\mathrm{CCN}$ concentration from the product of $\mathrm{CN}$ and GMD for widely varying aerosol size distributions is analogous to the better association between the product of the aerosol scattering coefficient and its spectral dependence (Ångström exponent) with $\mathrm{CCN}$ concentration rather than the regression between scattering coefficient and CCN concentration (Jayachandran et al., 2018).

In general, aerosol size distribution plays a major role in $\mathrm{CCN}$ activation. The ultrafine particles significantly decrease the activation efficiency compared to the fine-mode aerosols. Since the $\mathrm{CN}$ number concentration decreased from the southeastern Arabian Sea to the equatorial Indian Ocean, delineating the periods of ultrafine-particle dominance from a threshold $\mathrm{CN}$ value is difficult (see Fig. 4a). The $\mathrm{CN}$ values over the equatorial Indian Ocean $\left(>5000 \mathrm{~cm}^{-3}\right)$ during ultrafine-particle events are lower than the $\mathrm{CN}$ values without ultrafine-particle events over the southeastern Arabian Sea region. The association of $\mathrm{CCN}$ activation efficiency with the $\mathrm{CN}$ number concentration over different regions is shown in Fig. 5. For a constant $\mathrm{CN}$ concentration $\left(5000 \mathrm{~cm}^{-3}\right)$, the CCN activation efficiency at EIO $(\sim 15 \%)$ is much lower than that of SEAS1 $(\sim 65 \%)$ due to the presence of more ultrafine particles in EIO. Figure 5 highlights that the activation efficiency decreases with $\mathrm{CN}$ concentration following power-law dependence $\left(\mathrm{AE}=a \cdot \mathrm{CN}^{b}\right.$, where $\mathrm{a}$ and $\mathrm{b}$ are constants) with similar coefficients $\left(b=-0.84, R^{2}=0.85\right.$ ) over both SEAS1 and EIO regions. Yum et al. (2007) also showed that $\mathrm{CCN}$ efficiency decreases with the increase in ultrafineparticle concentrations irrespective of air mass type, which implies the lower hygroscopicity of these particles (Pierce and Adams, 2007).

The scatter plot between the CCN activation efficiency at $0.4 \%$ supersaturation and the GMD of aerosol size distribution segregated for different marine regions is shown in Fig. 6a. It is clear that the higher CCN activation efficiency is observed for particle size distributions dominated by larger particles (GMD > 130 nm) irrespective of the regions and air mass patterns. Wherever the contribution of ultrafine particles to the total aerosol concentration is significant, the activation efficiency decreased. In general, low (high) GMD values resulted in low (high) $\mathrm{CCN}$ activation efficiency, irrespective of aerosol composition, in the south Asian outflow. For a given GMD of $90 \mathrm{~nm}$, the activation efficiency varied over a wide range from $20 \%$ to $60 \%$, which is more notable over the EIO region (stars), where the ultrafine particles contribute $20 \%$ to $50 \%$ to the total number concentrations. Earlier, Kim et al. (2014) also observed a significant spread in the association between $\mathrm{CCN}$ at $0.6 \%$ supersaturation and a GMD in the range of $40-70 \mathrm{~nm}$, which is attributed to the

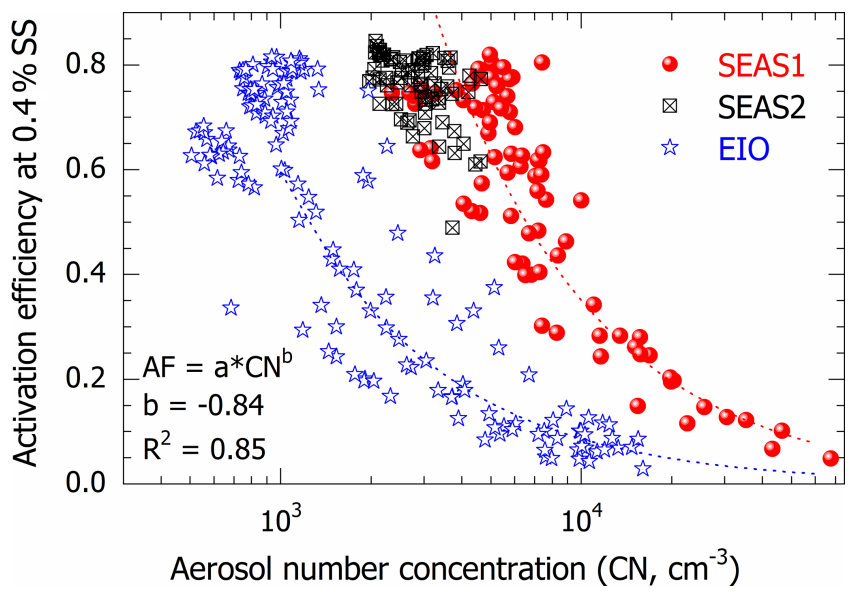

Figure 5. Association of activation efficiency at $0.4 \%$ supersaturation (SS) with $\mathrm{CN}$ number concentration during SEAS1, SEAS2 and EIO of ICARB-2018. Dotted lines indicate regression fit to the data.

heterogeneities in aerosol chemical composition. The association between the GMD and activation efficiency weakened during the new-particle formation events and aerosol size distributions having multiple modes, especially in the coarse- and ultrafine-particle regime. Supersaturation spectra of CCN activation efficiency for low $(25-50 \mathrm{~nm})$ and high $(125-150 \mathrm{~nm})$ values of the GMD are shown in Fig. 6b. In contrast to SEAS1 and EIO, low-GMD cases were not observed over SEAS2. For low-GMD cases, activation efficiency at $1.0 \%$ supersaturation is mostly less than $30 \%$ over SEAS1 and EIO, which implies the low hygroscopicity of the ultrafine particles. In contrast, higher activation efficiencies $(>60 \%)$ are observed for high-GMD cases over all the regions irrespective of the supersaturation conditions. The very low activation efficiency at $0.2 \%$ supersaturation $(\sim 30 \%)$ observed over the SEAS1 region increased drastically to $\sim 100 \%$ at $1.0 \%$ supersaturation for high-GMD conditions. Regionally, SEAS1 aerosols are more CCN active, especially at higher supersaturations $(1.0 \%)$ compared to the EIO aerosols (Fig. 6b).

The above discussions highlighted the significant role of the GMD and, in turn, the abundance of ultrafine aerosols in the activation efficiency of the aerosol system. This analysis broadly confirms the primary role of aerosol size distribution in deciding the $\mathrm{CCN}$ concentration and activation efficiency over the region. During ICARB-2018, GMD values varied from 25 to $160 \mathrm{~nm}$, and nearly $40 \%$ of the measurements have a GMD of less than $100 \mathrm{~nm}$. The high activation values are observed whenever the contribution of ultrafinemode aerosols to the $\mathrm{CN}$ is negligible. Also, higher $\mathrm{CN}$ values $\left(>10^{4} \mathrm{~cm}^{-3}\right)$ with low GMD values $(<60 \mathrm{~nm})$ are seen over both the SEAS1 and EIO regions suggesting newparticle formation events. A low CCN efficiency at $0.2 \%$ supersaturation at SEAS1 reinstates the dominance of ultrafine 

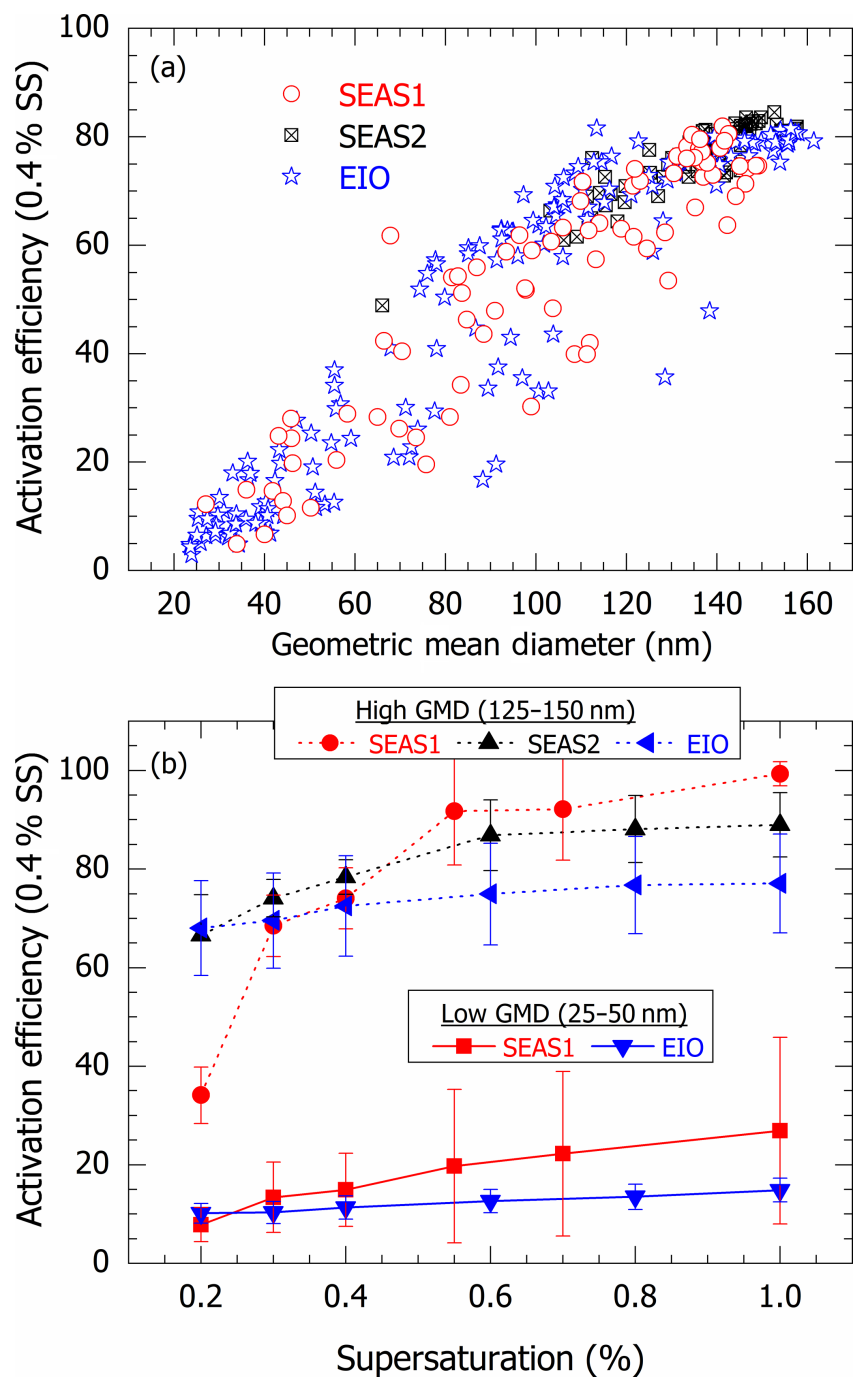

Figure 6. (a) Association of geometric mean diameter (GMD) with $\mathrm{CCN}$ activation efficiency at $0.4 \%$ supersaturation (SS) over SEAS1, SEAS2 and EIO during ICARB-2018. (b) Supersaturation spectra of activation efficiency for low $(25-50 \mathrm{~nm})$ and high (125$150 \mathrm{~nm}$ ) GMD values during SEAS1 and EIO. All the size distribution measurements during SEAS2 have a GMD above $50 \mathrm{~nm}$. Vertical bars on the symbol indicate the standard deviation of the measurements.

particles or the hydrophobic nature of the particles resulting from the continental outflow. It is well known that bimodal distribution is a characteristic of the aerosol system over the marine environment (one mode emanating from possible nucleation events and the other one in the lower size range of the fine mode), whereas aged continental outflows over the oceans show a unimodal distribution with a mode around 80 to $200 \mathrm{~nm}$ (Yum et al., 2007). The measurements of aerosol particle size distributions carried out over the Bay of Bengal during winter 2009 (ICARB-2009) revealed a unimodal size distribution with a mode diameter close to $100 \mathrm{~nm}$. This further supports the lack of ultrafine particles over SEAS2, where air masses mostly originate from the Bay of Bengal. At low supersaturations, marine aerosols have a higher $\mathrm{CCN}$ activation efficiency compared to the continentally influenced aerosol system, which flip-flops at higher supersaturations. This aspect is further investigated using the aerosol size distribution and critical diameter in the following section. The present study is also in line with the earlier observations reported over various oceanic regions, which depicted a higher activation efficiency for continental aerosols than clean marine aerosols (Yum et al., 2007). A strong association is observed between the GMD and a hygroscopicity parameter for different mixing state conditions (external, internal and internal with non-growth) over the Korean peninsula (Kim et al., 2018). The present study highlight that the higher activation efficiencies are observed for the continental or marine aerosols mostly in the absence of ultrafine-particle burst events.

\subsection{Aerosol size distribution and $\mathrm{CCN}$ activation}

To understand the effect of ultrafine particles on CCN activation, two typical cases have been considered over SEAS1 and EIO, where aerosol size distribution varied drastically within a few hours due to ultrafine-particle events which are characterized by low GMD values and a high number concentration of ultrafine particles (diameters $<100 \mathrm{~nm}$ ). Figure 7 shows the $\mathrm{CCN}$ spectra and activation efficiency along with the corresponding aerosol number size distribution over SEAS1 and EIO for high and low concentrations of ultrafine particles (high UFP and low UFP). Corresponding $k$ values (Twomey's empirical slope) are also mentioned in the figure. Over SEAS1, the variation in CCN with supersaturation for high- and low-UFP cases showed an almost similar pattern with a relatively steeper increase in $\mathrm{CCN}$ with supersaturation for high UFP compared to low UFP. The CCN activation efficiency for low-UFP case increased from $\sim 33 \%$ at $0.2 \%$ supersaturation to almost $100 \%$ at $1.0 \%$ supersaturation, whereas for high UFP the activation efficiency at the highest supersaturation $(1.0 \%)$ is only $\sim 45 \%$ over SEAS1. This significant difference in the activation efficiency for the two cases can mostly be attributed to the higher concentrations of ultrafine particles, as already mentioned in the earlier section and Fig. 7b. The particles below $100 \mathrm{~nm}$ contributed almost $37 \%$ to the total number concentration for the low-UFP case, and all these particles are activated at high supersaturation in contrast to the high-UFP case. The large amounts of ultrafine-particle concentrations (with a GMD of $\sim 50 \mathrm{~nm}$ in Fig. 7b) seen in the high-UFP case did not contribute significantly to the $\mathrm{CCN}$ concentrations even at $1.0 \%$ supersaturation.

Over EIO, though the $\mathrm{CCN}$ values at lower supersaturations are comparable for both the cases, a $100 \%$ increase is observed in $\mathrm{CCN}$ concentration at $1.0 \%$ supersaturation for high UFP compared to low UFP (Fig. 7c). The activation efficiency depicted an entirely distinct pattern with low values 

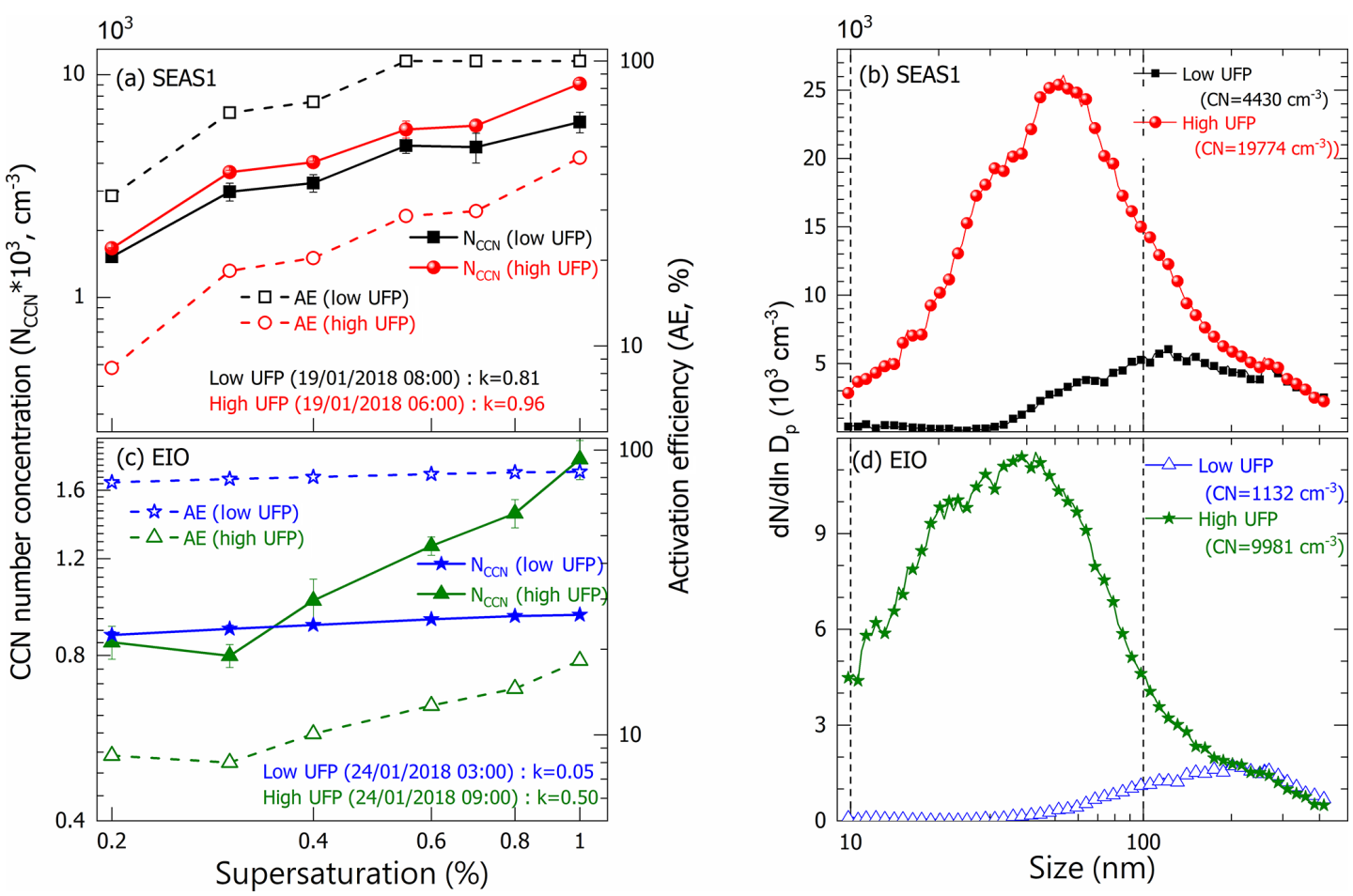

Figure 7. (a, c) Typical cases of supersaturation spectra of CCN number concentration and activation efficiency (AE) for high and low concentration of ultrafine particles (UFP) over SEAS1 and EIO. (b, d) The aerosol number size distributions corresponding to (a) and (c).

(20\%) at all supersaturations for high UFP compared to the activation efficiency of $>75 \%$ for the low-UFP case. These typical events over SEAS1 and EIO clearly demonstrate the lower activation efficiency of ultrafine aerosols. However, there exist strong differences in the activation properties of CCN over SEAS1 and EIO. For both high- and low-UFP cases, SEAS1 aerosols are more CCN active at higher supersaturations than EIO, which is also clearly reflected in the regional mean values. The absolute magnitude of $\mathrm{CCN}$ concentration is relatively less over EIO with no significant increase in $\mathrm{CCN}$ concentration with increasing supersaturation (especially for low UFP, $k \sim 0.05$ ). These flat CCN spectra (lower $k$ values $<0.5$ in both the cases) observed over EIO represent maritime aerosol. The high $k$ values $(>0.8)$ over SEAS1 represent polluted marine conditions (Jayachandran et al., 2017). The aerosol system can have a high and low activation efficiency or $k$ depending on the contribution of ultrafine-mode aerosols to the total number concentration. This is contrary to the general classification of the aerosol system based on $k$ (Jayachandran et al., 2017). The inverse relationship between the Twomey exponent $(k)$ and activation efficiency reported by Jayachandran et al. (2017) over coastal-location Thumba, which is geographically closer to SEAS1, does not hold during ICARB-2018 because of the new-particle formation events and the abundance of ultrafine particles. This is similar to high-UFP cases, as shown in Fig. 7.
To evaluate the relative importance of aerosol number size distribution in CCN activation, similar aerosol size distributions are grouped by regressing each individual size distribution with all the other size distributions. The size distribution having the maximum number of occurrences of the coefficient of determination $\left(R^{2}\right)$ greater than 0.9 is identified as the first group. Then, the first group of distributions are removed, and regression analysis is repeated to estimate the next major prominent size distribution (Fig. 8a). The mean number size distributions and corresponding mean activation efficiency at $0.4 \%$ supersaturation for each of the groups are shown in Fig. 8b. This analysis highlighted that the majority of the hourly mean size distributions (number $N \sim 119$ ) depicted a broad peak with the mode around 150-300 nm (Type 1) with the highest activation ratio of $76 \%$. Whenever the mode of the size distribution falls below $100 \mathrm{~nm}$, i.e., the mode is in the ultrafine-particle regime (Type 2, Type 5 and Type 6), a lower activation efficiency of value below $20 \%$ was observed. The Type 3 and Type 4 size distributions, which are similar to Type 1 but with a small difference in the particle concentration above $100 \mathrm{~nm}$, also showed a higher activation efficiency $(>70 \%)$. The spread seen in activation efficiency (standard deviation) for a "fixed" aerosol size distribution could be due to the difference in aerosol chemical composition. It should be kept in mind that, even though we grouped the similar distributions $\left(R^{2}>0.9\right)$, the small variations observed between the member distributions 

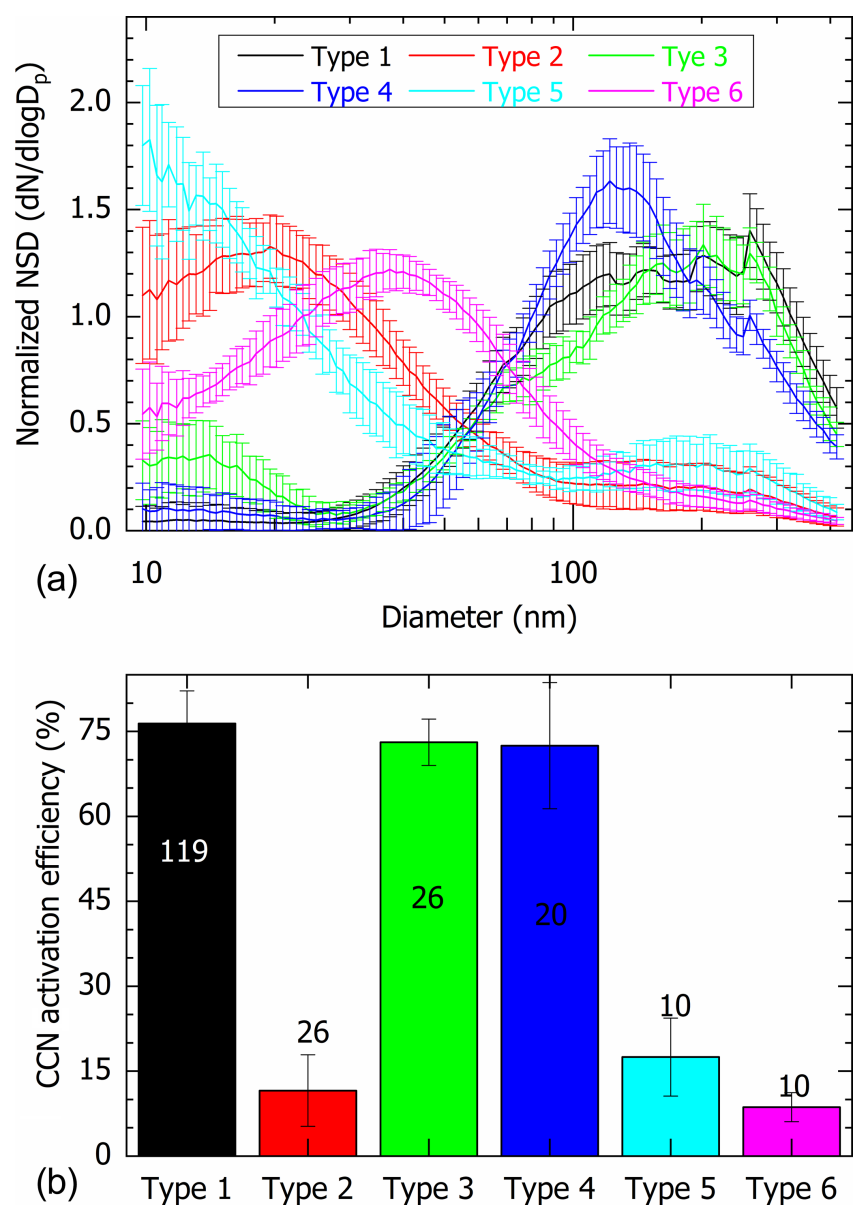

Figure 8. (a) Most frequently occurring aerosol number size distributions (normalized) during ICARB-2018. Vertical bars represent the standard deviation of the data, and the number of hourly observations averaged for each distribution is given in (b). (b) Activation efficiency at $0.4 \%$ supersaturation of the normalized distributions shown in panel (a).

(standard deviation of size distributions shown in Fig. 8a) can also contribute to the standard deviation of the activation efficiency. The difference between the activation efficiencies for two distinct size distributions is more substantial than their standard deviations, which initially implies the primary role of number size distribution on the $\mathrm{CCN}$ activation.

We have further examined the association of $\mathrm{CCN}$ concentration with aerosol number concentration $(\mathrm{d} N)$ at different size ranges. Figure 9a shows the scatter plot of $\mathrm{CCN}$ concentration with the cumulative aerosol number concentration above the size range of $50 \mathrm{~nm}\left(N_{50}\right), 100 \mathrm{~nm}\left(N_{100}\right)$ and $150 \mathrm{~nm}\left(N_{150}\right)$. The slope of the regression fit and coefficients of determination $\left(R^{2}\right)$ estimated for the $\mathrm{CCN}$ and aerosol concentrations above different size ranges (up to $N_{250}$ ) are shown in Fig. 9b. The slope of the regression analysis increased as the lower size cut of the aerosol number concentration increased from 50 to $250 \mathrm{~nm}$. The coefficient of determination $\left(R^{2}\right)$ was low for $N_{50}$ and increased
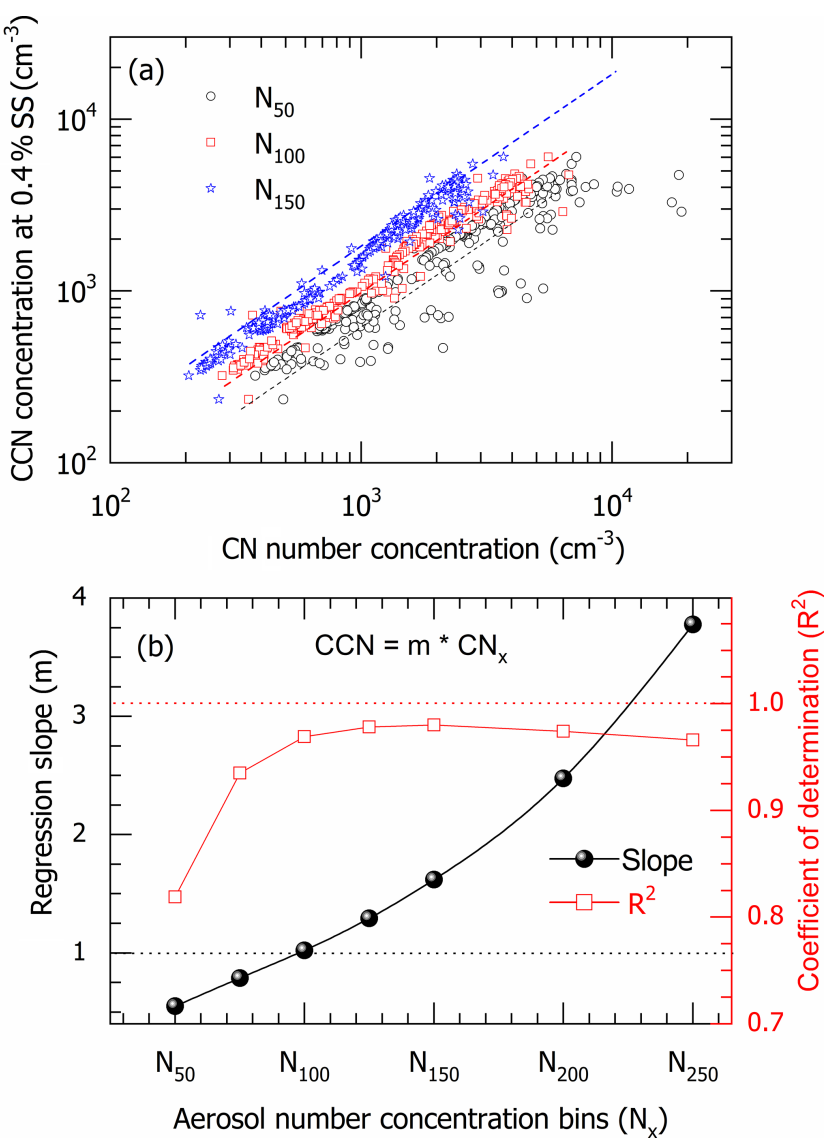

Figure 9. (a) Scatter plot between $\mathrm{CCN}$ number concentrations at $0.4 \%$ supersaturation (SS) with aerosol number concentration (CN) for particles size larger than 50, 100 and $150 \mathrm{~nm}$. (b) Variation in regression coefficients (slope and $R^{2}$ ) estimated for $\mathrm{CCN}$ at $0.4 \%$ supersaturation with aerosol number concentration at different size ranges. The $N_{50}$ indicate aerosol number concentration above $50 \mathrm{~nm}$.

to 0.98 for $N_{100}$. The $\mathrm{CCN}$ varied with $\mathrm{CN}$ concentration where the slope of the variation strongly depended on the size distribution and is stronger for larger aerosols (GMD values $>100 \mathrm{~nm}$ as shown in Fig. 4) and weaker for ultrafinemode aerosols. The scatter between $\mathrm{CCN}$ at $0.4 \%$ supersaturation and $\mathrm{CN}_{100}$ shows better association (slope $\sim 0.95$ and $R^{2} \sim 0.92$ ). This implies that most of the particles above $100 \mathrm{~nm}$ are $\mathrm{CCN}$ at $0.4 \%$ supersaturation and $N_{100}$ is a good proxy for $\mathrm{CCN}$ concentration at $0.4 \%$ supersaturation. The contribution of particles to the $\mathrm{CCN}$ concentration at $0.4 \%$ supersaturation is lower above $100 \mathrm{~nm}$. For the particles above $200 \mathrm{~nm}, \mathrm{CCN}$ concentration is nearly 2.5 times higher than the $N_{200}$.

The above analysis indicates that the critical activation diameter, which is the size above which all the aerosols become activated as $\mathrm{CCN}$ (at $0.4 \%$ supersaturation) is close to $100 \mathrm{~nm}$ for the continental outflow of aerosols to the northern Indian Ocean during wintertime. The critical activation 
diameter of the aerosol system can be experimentally estimated from size-segregated CCN measurements (Rose et al., 2010) or from the simultaneous observations of CCN and aerosol number size distributions (Furutani et al., 2008). Assuming an internally mixed aerosol system, we have estimated the "apparent critical diameter" for a particular supersaturation by integrating the aerosol number concentration $(\mathrm{d} N)$ from a higher to a lower size range in such way that estimated aerosol number concentration equals $\mathrm{CCN}$ concentration (Burkart et al., 2011) and the diameter corresponding to that is called the critical diameter. The cumulative number concentration (summing from higher size to lower) and critical diameter for different supersaturations over SEAS1, SEAS2 and EIO are shown in Fig. 10a and b. As seen in Fig. 10a, the contribution of ultrafine particles to the total concentration is relatively high over SEAS1 compared to SEAS2 and EIO due to the continental proximity. As expected, the critical diameter was lower for higher supersaturations for all the regions. This is consistent with the Kohler theory. A relatively large decrease in critical diameter with supersaturation was observed over SEAS1 compared to SEAS2 and EIO. As shown in Fig. 2, though the aerosol loading is high over SEAS1, CCN concentration at $0.2 \%$ supersaturation is lower over SEAS1 compared to that of EIO. The high value of the critical diameter $(\sim 185 \mathrm{~nm})$ over SEAS1 further confirms that only a small portion of the aerosol population is activated as $\mathrm{CCN}$ at $0.2 \%$ supersaturation. This is mostly attributed to the presence of less hygroscopic aerosols (possibly carbonaceous) above $100 \mathrm{~nm}$ size range, which requires higher supersaturation to become activated. In contrast, the lower critical diameter at $1.0 \%$ supersaturation over SEAS1 could be attributed to the watersoluble aerosol in the ultrafine-particle mode. It is interesting to note that the critical diameter at $1.0 \%$ supersaturation is higher for EIO than SEAS1 in contrast with $0.2 \%$ and $0.4 \%$ supersaturations. This observation is in line with the high activation efficiency at $1.0 \%$ supersaturation over SEAS1 compared to EIO (Fig. 6).

Simultaneous measurements of aerosol number size distribution and $\mathrm{CCN}$ at different supersaturation are useful in understanding $\mathrm{CCN}$ characteristics. The size distribution over SEAS1 has a mode close to $100 \mathrm{~nm}$, which represents the influence of polluted continental air mass. Ueda et al. (2016) reported bimodal size distributions as a typical maritime aerosol system based on the extensive measurements of aerosol number size distributions over the Pacific Ocean covering $40^{\circ} \mathrm{N}$ to $40^{\circ} \mathrm{S}$. However, most of the measurements during ICARB-2018 depicted broad mono-modal distribution indicating the aged, continental outflow aerosols. The bimodal distributions are less frequent and mostly associated with ultrafine-particle bursts (Fig. 8). A fine mode has been consistently present in the aerosol number size distribution over SEAS, which is contributing to the high CCN activation. The regional difference in the aerosol number size distribution and its role in determining the activation effi-
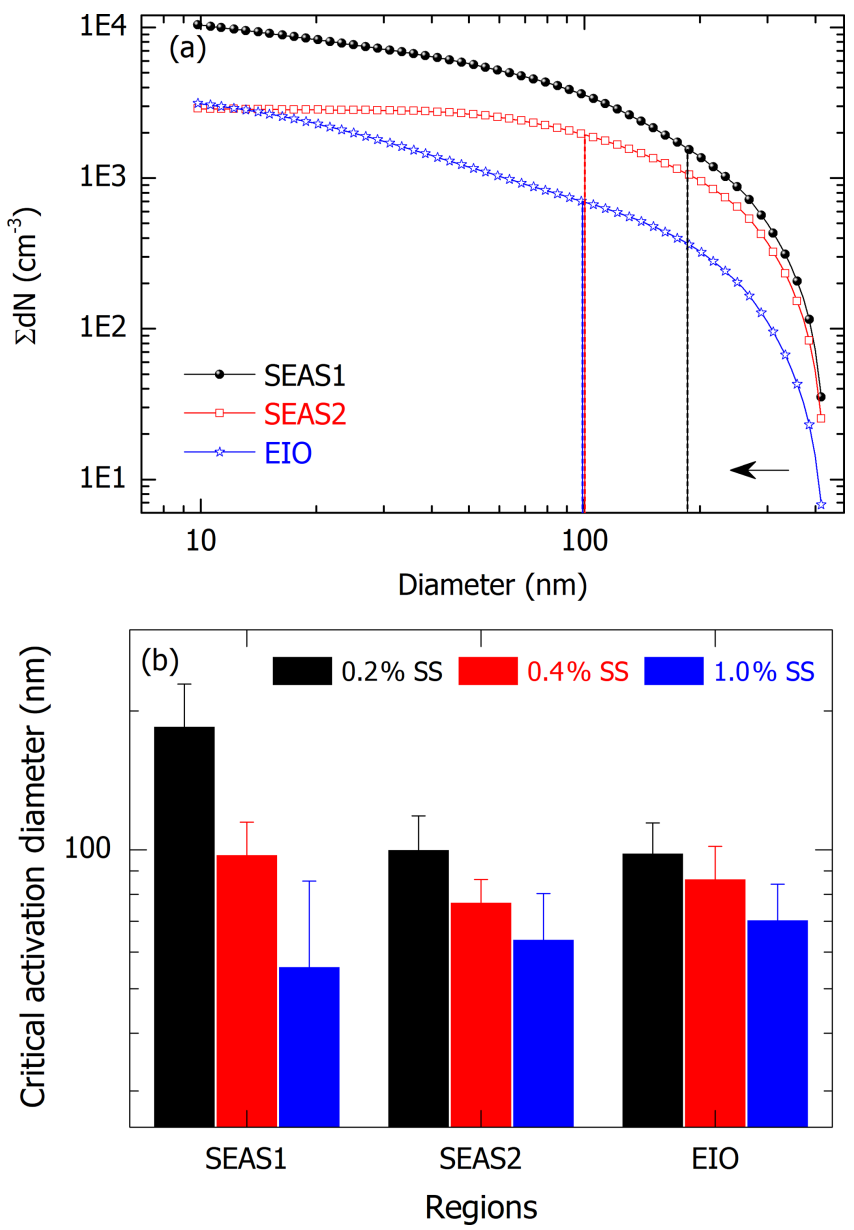

Figure 10. (a) Cumulative aerosol number concentration from higher size range to lower over SEAS1, SEAS2 and EIO. The value at $9 \mathrm{~nm}$ indicates the total number concentration. The apparent critical activation diameter is shown as dashed vertical lines. (b) Variation in critical diameter for $0.2 \%, 0.4 \%$ and $1.0 \%$ supersaturations (SS) over SEAS1, SEAS2 and EIO.

ciency of $\mathrm{CCN}$ are vivid such that the dominance of fine or ultrafine particles decreases the CCN efficiency from the expected values. Kalivitis et al. (2015) investigated the association of $\mathrm{CCN}$ at $0.2 \%$ supersaturation with aerosol concentrations larger than the threshold diameter (from 80 to $130 \mathrm{~nm}$ ) over the eastern Mediterranean marine atmospheric boundary layer. These authors reported particle concentrations above $100 \mathrm{~nm}$ as the best indicator for $\mathrm{CCN}$ at $0.2 \% \mathrm{su}-$ persaturation over the region, and the present study supports this finding (Fig. 9). Burkart et al. (2011) attributed the high critical diameter of aerosols at $0.5 \%$ supersaturation over $\mathrm{Vi}$ enna to the presence of insoluble aerosols. Rose et al. (2010) have reported a dry activation diameter of 200 to $30 \mathrm{~nm}$ for a wide range of supersaturations of $0.068 \%$ to $1.27 \%$.

The presence of significant amounts of ultrafine particles observed over the northern Indian Ocean could be attributed to the in situ new-particle formation events and/or transport 
from the free troposphere. The ICARB-2018 measurements indicate that these ultrafine-particle events are mostly observed during the early morning and evening hours. A nearly $20 \%$ to $40 \%$ increase in the mass concentration of organic carbon (OC) was observed during such conditions, implying the formation of secondary organic aerosols. A largescale anticyclonic system prevailed during the wintertime over the region and also supported the amalgamation of distinct air masses and intrusion of ultrafine particles formed in the free troposphere into the lower atmosphere. The absence of a very high concentration of nucleation aerosols $(<10 \mathrm{~nm})$ further confirms the possibility of the transport of free-tropospheric aerosols. Nair et al. (2013) have reported ultrafine-particle dominance over the northern Arabian Sea during spring 2006, which was strongly associated with the variation in chlorophyll concentrations implying a role of ocean biogeochemistry. However, the role of ocean biogeochemistry and that of the semi-volatile organic vapours in the formation of ultrafine particles over the northern Indian Ocean needs to be investigated in detail.

Since the CCN activity depends mainly on the aerosol size and composition (Dusek et al., 2006a), the critical diameter can be regarded as a proxy for the variations in the chemical composition of the aerosol system. It should be emphasized that the aerosol size distribution and chemical composition are intrinsically coupled with each other, and any change in the aerosol size distribution may have also been due to aerosol composition differences. Quinn et al. (2008) have correlated the critical diameter with the hydrogenated organics aerosol (HOA) mass concentration and found that HOA can explain about $40 \%$ of the variance in the critical diameter. For anthropogenic and marine environments, Furutani et al. (2008) have reported a critical diameter of 70-110 and $50-60 \mathrm{~nm}$ respectively at $0.6 \%$ supersaturation. The critical diameter estimated for the South Asian outflow is comparable to the values of $70-90 \mathrm{~nm}$ (at $0.44 \%$ supersaturation) reported by Quinn et al. (2008) for marine regions. It should be noted that the freshly emitted carbonaceous combustion particles have a high critical diameter $(\sim 350 \mathrm{~nm})$ even at a high supersaturation $(0.7 \%)$ as reported by Dusek et al. (2006b). The presence of soluble aerosols largely enhances the CCN activity of insoluble particles such as BC and dust (Dusek et al., 2006b) due to effective mixing. Thus, these inferences underline the need for observations of mixing state that are more realistic and size-segregated aerosol composition measurements in regions like SEAS, where primary as well as secondary particles are present from both natural and anthropogenic sources.

This study highlighted the high concentration of $\mathrm{CCN}$ over the South Asian outflow regions. The relative importance of aerosol size distribution and chemical composition in CCN activation has been the topic of investigation for several experiments (Dusek et al., 2006a; Kerminan et al., 2012; Hudson, 2007). A significant understanding of the critical diameter (Kerminan et al., 2012) and size-segregated hygroscopic- ity parameter $(\kappa)$ (Petters and Kreidenweis, 2007) enabled us to predict the $\mathrm{CCN}$ concentration based on the measurement of physical and chemical properties of aerosols carried out at distinct environments (Schmale et al., 2018). Paramonov et al. (2015) have shown that the hygroscopicity parameter decreases with particle size, with the ultrafine- and fine-mode aerosols having a statistically significant difference in hygroscopicity values. Our observations with the lower activation efficiency observed for distributions with ultrafine-particle dominance agree with Paramonov et al. (2015). Several studies have considered an average size distribution of aerosols with a varying hygroscopicity parameter to predict $\mathrm{CCN}$ concentration (Rose et al., 2010; Gunthe et al., 2009; Jurányi et al., 2010). These studies also emphasized that aerosol size distribution has a major role in deciding the number concentration of CCN. Meng et al. (2014) reported that hygroscopicity is more critical at low supersaturations and not at high supersaturations. While the present study described the CCN characteristics over the different parts of the northern Indian Ocean and its association with particle number size distributions, further studies are required to examine the climate implications of these observations.

\section{Conclusions}

Extensive measurements of aerosol and $\mathrm{CCN}$ properties in South Asian outflow to the northern Indian Ocean were carried out as a part of the ICARB-2018 experiment during January-February 2018. The influence of continental outflow on the $\mathrm{CCN}$ characteristics over the marine atmospheric boundary layer extending from $15^{\circ} \mathrm{N}$ to $2^{\circ} \mathrm{S}$ (southeast Arabian Sea and the equatorial Indian Ocean) close to the Indian subcontinent were investigated. The major highlights of this study are the following.

- High CCN concentrations are seen over the southeastern Arabian Sea, with steep $(k=0.83) \mathrm{CCN}$ spectra, while low $k$ values are observed at the equatorial Indian Ocean;

- Most of the aerosols (>75\%) in the South Asian outflow (over SEAS) are CCN at high (1.0\%) supersaturations, whereas the aerosol system over the equatorial Indian Ocean is less $\mathrm{CCN}$ efficient $(53 \pm 28 \%)$ at higher supersaturations.

- The CCN efficiency depicts a strong association with the geometrical mean diameter of the aerosol number size distribution. The activation efficiency decreases with greater dominance of ultrafine particles.

- Fine-mode particles $(>100 \mathrm{~nm}$ ) contribute to the high activation efficiency (69\%) over the northern Indian Ocean. The number concentration of particles above $100 \mathrm{~nm}$ is a good proxy for predicting $\mathrm{CCN}$ number concentration at $0.4 \%$ supersaturation. 
The formation and transport pathways of ultrafine particles over the region during the winter season remain an open question at present, and more dedicated field experiments and detailed investigations are required to address this in detail. Though the variations in the GMD of the aerosol number size distributions account for the variability in $\mathrm{CCN}$ activation efficiency over the southeastern Arabian Sea and the equatorial Indian Ocean, the change in aerosol chemistry associated with the ultrafine-particle burst events during the early morning and evening hours needs further investigation using the size-segregated $\mathrm{CCN}$ measurements and online measurements of aerosol chemistry.

Data availability. ICARB-2018 data are available upon request from the contact author, Vijayakumar S. Nair (vijayakumar_s@vssc.gov.in).

Author contributions. SSB and VSN designed the experiment. VSN, JV, SKK, MMG and SSB involved in the data collection onboard ship. VSN did the scientific analysis of the data and drafted the paper. SSB edited the paper.

Competing interests. The authors declare that they have no conflict of interest.

Special issue statement. This article is part of the special issue "Interactions between aerosols and the South West Asian monsoon". It is not associated with a conference.

Acknowledgements. The ICARB-2018 experiment was carried out under the ISRO Geosphere-Biosphere Programme. Authors acknowledge the National Centre for Polar and Ocean Research (NCPOR) of the Ministry of Earth Sciences of the government of India for providing the shipboard facilities onboard ORV Sagar Kanya. We acknowledge NOAA ARL for providing the Hybrid SingleParticle Lagrangian Integrated Trajectory (HYSPLIT) transport and dispersion model used in this study.

Review statement. This paper was edited by B. V. Krishna Murthy and reviewed by James Hudson and one anonymous referee.

\section{References}

Ackerman, A. S., Toon, O. B., Stevens, D. E., Heymsfield, A. J., Ramanathan, V., and Welton, E. J.: Reduction of tropical cloudiness by soot, Science, 288, 1042-1047, https://doi.org/10.1126/science.288.5468.1042, 2000.

Andreae, M. O.: Correlation between cloud condensation nuclei concentration and aerosol optical thickness in remote and polluted regions, Atmos. Chem. Phys., 9, 543-556, https://doi.org/10.5194/acp-9-543-2009, 2009.

Bharali, C., Nair, V. S., Chutia, L., and Babu, S. S.: Modeling of the effects of wintertime aerosols on boundary layer properties over the Indo Gangetic Plain, J. Geophys. Res.-Atmos., 124, 41414157, https://doi.org/10.1029/2018JD029758, 2019.

Burkart, J., Steiner, G., Reischl, G., and Hitzenberger, R.: Longterm study of cloud condensation nuclei $(\mathrm{CCN})$ activation of the atmospheric aerosol in Vienna, Atmos. Environ., 45, 5751-5759, 2011.

Cantrell, W., Shaw, G., Leck, C., Granat, L., and Cachier, H.: Relationships between cloud condensation nuclei spectra and aerosol particles on a south-north transect of the Indian Ocean, J. Geophys. Res., 105, 15313-15320, 2000.

Cantrell, W., Shaw, G., Cass, G., Chowdhury, Z., Hughes, L., Prather, K., Guazzotti, S., and Coffee, K.: Closure between aerosol particles and cloud condensation nuclei at Kaashidhoo Climate Observatory, J. Geophys. Res., 106, 28711-28718, 2001.

Chylek, P., Dubey, M. K., Lohmann, U., Ramanathan, V., Kaufman, Y. J., Lesins, G., Hudson, J., Altmann, G., and Olsen, S. C.: Aerosol indirect effect over the Indian Ocean, Geophys. Res. Lett., 33, L06806, https://doi.org/10.1029/2005GL025397, 2006.

Dusek, U., Frank, G. P., Hildebrandt, L., Curtius, J., Schneider, J., Walter, S., Chand, D., Drewnick, F., Hings, S., Jung, D., Borrmann, S., and Andreae, M. O.: Size matters more than chemistry for cloud-nucleating ability of aerosol particles, Science, 312, 1375-1378, 2006a.

Dusek, U., Reischl, G. P., and Hitzenberger, R.: CCN Activation of Pure and Coated Carbon Black Particles, Environ. Sci. Technol., 40, 1223-1230, 2006b.

Fang, S., Han, Y., Chen, K., Lu, C., Yin, Y., Tan, H., and Wang, J.: Parameterization and comparative evaluation of the CCN number concentration on Mt. Huang, China, Atmos. Res., 181, 300-311, 2016.

Furutani, H., Dall'osto, M., Roberts, G. C., and Prather, K. A.: Assessment of the relative importance of atmospheric aging on $\mathrm{CCN}$ activity derived from field observations, Atmos. Environ., 42, 3130-3142, 2008.

Gunthe, S. S., King, S. M., Rose, D., Chen, Q., Roldin, P., Farmer, D. K., Jimenez, J. L., Artaxo, P., Andreae, M. O., Martin, S. T., and Pöschl, U.: Cloud condensation nuclei in pristine tropical rainforest air of Amazonia: size-resolved measurements and modeling of atmospheric aerosol composition and CCN activity, Atmos. Chem. Phys., 9, 7551-7575, https://doi.org/10.5194/acp9-7551-2009, 2009.

Hudson, J. G.: Variability of the relationship between particle size and cloud-nucleating ability, Geophys. Res. Lett., 34, L08801, https://doi.org/10.1029/2006GL028850, 2007.

Hudson, J. G. and Yum, S. S.: Cloud condensation nuclei spectra and polluted and clean clouds over the Indian Ocean, J. Geophys. Res., 107, 8022, https://doi.org/10.1029/2001JD000829, 2002.

Hudson, J. G., Noble, S., and Tabor, S.: Cloud supersaturations from CCN spectra Hoppel minima, J. Geophys. Res.-Atmos., 120, 3436-3452, https://doi.org/10.1002/2014JD022669, 2015.

IPCC: Climate Change 2013: The Physical Science Basis, in: Contribution of Working Group I to the Fifth Assessment Report of the Intergovernmental Panel on Climate Change, Cambridge 
University Press, Cambridge, UK and New York, NY, USA, 2013.

Jayachandran, V., Nair, V. S., and Babu, S. S.: CCN characteristics over a tropical coastal station during south-west monsoon: observations and closure studies, Atmos. Environ. 164, 299-308, https://doi.org/10.1016/j.atmosenv.2017.06.012, 2017.

Jayachandran, V., Nair, V. S., and Babu, S. S.: CCN activation properties at a tropical hill station during south-west summer monsoon: Vertical heterogeneity, Atmos. Res., 214, 36-45, https://doi.org/10.1016/j.atmosres.2018.07.018, 2018.

Jayachandran, V. N., Suresh Babu, S. N., Vaishya, A., Gogoi, M. M., Nair, V. S., Satheesh, S. K., and Krishna Moorthy, K.: Altitude profiles of cloud condensation nuclei characteristics across the Indo-Gangetic Plain prior to the onset of the Indian summer monsoon, Atmos. Chem. Phys., 20, 561-576, https://doi.org/10.5194/acp-20-561-2020, 2020.

Jefferson, A.: Empirical estimates of $\mathrm{CCN}$ from aerosol optical properties at four remote sites, Atmos. Chem. Phys., 10, 68556861, https://doi.org/10.5194/acp-10-6855-2010, 2010.

Jimenez, J. L., Canagaratna, M. R., Donahue, N. M., Prevot, A. S. H., Zhang, Q., Kroll, J. H., DeCarlo, P. F., Allan, J. D., Coe, H., Ng, N. L., Aiken, A. C., Docherty, K. S., Ulbrich, I. M., Grieshop, A. P., Robinson, A. L., Duplissy, J., Smith, J. D., Wilson, K. R., Lanz, V. A., Hueglin, C., Sun, Y. L., Tian, J., Laaksonen, A., Raatikainen, T., Rautiainen, J., Vaattovaara, P., Ehn, M., Kulmala, M., Tomlinson, J. M., Collins, D. R., Cubison, M. J., Dunlea, E. J., Huffman, J. A., Onasch, T. B., Alfarra, M. R., Williams, P. I., Bower, K., Kondo, Y., Schneider, J., Drewnick, F., Borrmann, S., Weimer, S., Demerjian, K., Salcedo, D., Cottrell, L., Griffin, R., Takami, A., Miyoshi, T., Hatakeyama, S., Shimono, A., Sun, J. Y., Zhang, Y. M., Dzepina, K., Kimmel, J. R., Sueper, D., Jayne, J. T., Herndon, S. C., Trimborn, A. M., Williams, L. R., Wood, E. C., Middlebrook, A. M., Kolb, C. E., Baltensperger, U., and Worsnop, D. R.: Evolution of organic aerosols in the atmosphere, Science, 326, 1525-1529, 2009.

Jurányi, Z., Gysel, M., Weingartner, E., DeCarlo, P. F., Kammermann, L., and Baltensperger, U.: Measured and modelled cloud condensation nuclei number concentration at the high alpine site Jungfraujoch, Atmos. Chem. Phys., 10, 7891-7906, https://doi.org/10.5194/acp-10-7891-2010, 2010.

Kalivitis, N., Kerminen, V.-M., Kouvarakis, G., Stavroulas, I., Bougiatioti, A., Nenes, A., Manninen, H. E., Petäjä, T., Kulmala, M., and Mihalopoulos, N.: Atmospheric new particle formation as a source of $\mathrm{CCN}$ in the eastern Mediterranean marine boundary layer, Atmos. Chem. Phys., 15, 9203-9215, https://doi.org/10.5194/acp-15-9203-2015, 2015.

Kerminen, V.-M., Paramonov, M., Anttila, T., Riipinen, I., Fountoukis, C., Korhonen, H., Asmi, E., Laakso, L., Lihavainen, H., Swietlicki, E., Svenningsson, B., Asmi, A., Pandis, S. N., Kulmala, M., and Petäjä, T.: Cloud condensation nuclei production associated with atmospheric nucleation: a synthesis based on existing literature and new results, Atmos. Chem. Phys., 12, 12037 12059, https://doi.org/10.5194/acp-12-12037-2012, 2012.

Kim, J. H., Yum, S. S., Shim, S., Kim, W. J., Park, M., Kim, J.H., Kim, M.-H., and Yoon, S.-C.: On the submicron aerosol distributions and $\mathrm{CCN}$ number concentrations in and around the Korean Peninsula, Atmos. Chem. Phys., 14, 8763-8779, https://doi.org/10.5194/acp-14-8763-2014, 2014.
Kim, N., Park, M., Yum, S. S., Park, J. S., Shin, H. J., and Ahn, J. Y.: Impact of urban aerosol properties on cloud condensation nuclei (CCN) activity during the KORUS-AQ field campaign, Atmos. Enviro., 185, 221-236, 2018.

Lelieveld, J., Crutzen, P. J., Ramanathan, V., Andreae, M. O., Brennikmeijer, C. A. M., Campos, T., Cass, G. R., Dickerson, R., Fischer, H., De Gouw, J. A., Hansel, A., Jefferson, A., Kley, D., DeLaat, A. T. J., Lal, S., Lawrence, M. G., Lobert, J. M., MayolBracero, O. L., Mitra, A. P., Novakov, T., Oltmans, S. J.,Prather, K. A., Rodhe, H., Scheeren, H. A., Sikka, D., and Williams, J.: The Indian Ocean Experiment: Widespread air pollution from South and South East Asia, Science, 292, 1031-1036, 2001.

Li, Z., Lau, W. K.-M., Ramanathan, V., Wu, G., Ding, Y., Manoj, M. G., Liu, J., Qian, Y., Li, J., Zhou, T., Fan, J., Rosenfeld, D., Ming, Y., Wang, Y., Huang, J., Wang, B., Xu, X., Lee, S.-S., Cribb, M., Zhang, F., Yang, X., Zhao, C., Takemura, T., Wang, K., Xia, X., Yin, Y., Zhang, H., Guo, J., Zhai, P. M., Sugimoto, N., Babu, S. S., and Brasseur, G. P.: Aerosol and monsoon climate interactions over Asia, Rev. Geophys., 54, 866-929, https://doi.org/10.1002/2015RG000500, 2016.

Mayol-Bracero, O. L., Gabriel, R., Andreae, M. O., Kirchstetter, T. W., Novakov, T., Ogren, J., Sheridan, P., and Streets, D. G.: Carbonaceous aerosols over the Indian Ocean during the Indian Ocean Experiment (INDOEX): Chemical characterization, optical properties, and probable sources, J. Geophys. Res., 107, 8030, https://doi.org/10.1029/2000JD000039, 2002.

Meng, J. W., Yeung, M. C., Li, Y. J., Lee, B. Y. L., and Chan, C. K.: Size-resolved cloud condensation nuclei (CCN) activity and closure analysis at the HKUST Supersite in Hong Kong, Atmos. Chem. Phys., 14, 10267-10282, https://doi.org/10.5194/acp-1410267-2014, 2014.

Merikanto, J., Spracklen, D. V., Mann, G. W., Pickering, S. J., and Carslaw, K. S.: Impact of nucleation on global CCN, Atmos. Chem. Phys., 9, 8601-8616, https://doi.org/10.5194/acp-9-86012009, 2009.

Moorthy K. K., Nair, V. S., Babu S. S., and Satheesh, S. K.: Spatial and vertical heterogeneities of aerosol radiative forcing over the oceanic regions surrounding the Indian peninsula: climate implications, Q. J. Roy. Meteor. Soc., 135, 2131-2145, 2009.

Nair, V. S., Moorthy, K. K., Alappattu, D. P., Kunhikrishnan, P. K., George, S. K., Nair, P. R., Babu, S. S., Abish, B., Satheesh, S. K., Tripathy, S. N., Niranjan, K., Madhavan, B. L., Srikant, V., Dutt, C. B. S., Badarinath, K. V. S., and Reddy, R. R.: Wintertime aerosol characteristics over the Indo-Gangetic Plain (IGP): Impacts of local boundary layer processes and long range transport, J. Geophys. Res.-Atmos., 112, D13205, https://doi.org/10.1029/2006JD008099, 2007.

Nair, V. S., Moorthy, K. K., and Babu, S. S.: Influence of continental outflow and ocean biogeochemistry on the distribution of fine and ultrafine particles in the marine atmospheric boundary layer over Arabian Sea and Bay of Bengal, J. Geophys. Res.-Atmos., 118, 7321-7337, https://doi.org/10.1002/jgrd.50541, 2013.

Noble, S. R. and Hudson, J. G.: Effects of continental clouds on surface Aitken and accumulation modes, J. Geophys. Res.-Atmos., 124, 5479-5502, https://doi.org/10.1029/2019JD030297, 2019.

Paramonov, M., Kerminen, V.-M., Gysel, M., Aalto, P. P., Andreae, M. O., Asmi, E., Baltensperger, U., Bougiatioti, A., Brus, D., Frank, G. P., Good, N., Gunthe, S. S., Hao, L., Irwin, M., Jaatinen, A., Jurányi, Z., King, S. M., Kortelainen, A., Kristensson, 
A., Lihavainen, H., Kulmala, M., Lohmann, U., Martin, S. T., McFiggans, G., Mihalopoulos, N., Nenes, A., O'Dowd, C. D., Ovadnevaite, J., Petäjä, T., Pöschl, U., Roberts, G. C., Rose, D., Svenningsson, B., Swietlicki, E., Weingartner, E., Whitehead, J., Wiedensohler, A., Wittbom, C., and Sierau, B.: A synthesis of cloud condensation nuclei counter (CCNC) measurements within the EUCAARI network, Atmos. Chem. Phys., 15, 12211-12229, https://doi.org/10.5194/acp-15-12211-2015, 2015.

Petters, M. D. and Kreidenweis, S. M.: A single parameter representation of hygroscopic growth and cloud condensation nucleus activity, Atmos. Chem. Phys., 7, 1961-1971, https://doi.org/10.5194/acp-7-1961-2007, 2007.

Pierce, J. R. and Adams, P. J.: Efficiency of cloud condensation nuclei formation from ultrafine particles, Atmos. Chem. Phys., 7, 1367-1379, https://doi.org/10.5194/acp-7-1367-2007, 2007.

Pöhlker, M. L., Pöhlker, C., Ditas, F., Klimach, T., Hrabe de Angelis, I., Araújo, A., Brito, J., Carbone, S., Cheng, Y., Chi, X., Ditz, R., Gunthe, S. S., Kesselmeier, J., Könemann, T., Lavrič, J. V., Martin, S. T., Mikhailov, E., Moran-Zuloaga, D., Rose, D., Saturno, J., Su, H., Thalman, R., Walter, D., Wang, J., Wolff, S., Barbosa, H. M. J., Artaxo, P., Andreae, M. O., and Pöschl, U.: Longterm observations of cloud condensation nuclei in the Amazon rain forest - Part 1: Aerosol size distribution, hygroscopicity, and new model parametrizations for CCN prediction, Atmos. Chem. Phys., 16, 15709-15740, https://doi.org/10.5194/acp-16-157092016, 2016.

Quinn, P. K., Bates, T. S., Coffman, D. J., and Covert, D. S.: Influence of particle size and chemistry on the cloud nucleating properties of aerosols, Atmos. Chem. Phys., 8, 1029-1042, https://doi.org/10.5194/acp-8-1029-2008, 2008.

Ramanathan, V., Crutzen, P. J., Lelieveld, J., Mitra, A. P., Althausen, D., Anderson, J., Andreae, M. O., Cantrell, W., Cass, G. R., Chung, C. E., Clarke, A. D., Coakley, J. A., Collins, W. D., Conant, W. C., Dulac, F., Heintzenberg, J., Heymsfield, A. J., Holben, B., Howell, S., Hudson, J., Jayaraman, A., Kiehl, J. T., Krishnamurti, T. N., Lubin, D., McFarquhar, G., Novakov, T., Ogren, J. A., Podgorny, I. A., Prather, K., Priestley, K., Prospero, J. M., Quinn, P. K., Rajeev, K., Rasch, P., Rupert, S., Sadourny, R., Satheesh, S. K., Shaw, G. E., Sheridan, P., and Valero, F. P. J.: Indian Ocean Experiment: an integrated analysis of the climate forcing and effects of the great Indo-Asian haze, J. Geophys. Res., 106, 28371-28398, 2001.

Reutter, P., Su, H., Trentmann, J., Simmel, M., Rose, D., Gunthe, S. S., Wernli, H., Andreae, M. O., and Pöschl, U.: Aerosol- and updraft-limited regimes of cloud droplet formation: influence of particle number, size and hygroscopicity on the activation of cloud condensation nuclei (CCN), Atmos. Chem. Phys., 9, 70677080, https://doi.org/10.5194/acp-9-7067-2009, 2009.

Roberts, G. C. and Nenes, A.: A continuous-flow streamwise thermal-gradient $\mathrm{CCN}$ chamber for atmospheric measurements., Aerosol Sci. Tech., 39, 206-221, 2005.

Rose, D., Nowak, A., Achtert, P., Wiedensohler, A., Hu, M., Shao, M., Zhang, Y., Andreae, M. O., and Pöschl, U.: Cloud condensation nuclei in polluted air and biomass burning smoke near the mega-city Guangzhou, China - Part 1: Size-resolved measurements and implications for the modeling of aerosol particle hygroscopicity and CCN activity, Atmos. Chem. Phys., 10, 33653383, https://doi.org/10.5194/acp-10-3365-2010, 2010.
Rose, D., Gunthe, S. S., Su, H., Garland, R. M., Yang, H., Berghof, M., Cheng, Y. F., Wehner, B., Achtert, P., Nowak, A., Wiedensohler, A., Takegawa, N., Kondo, Y., Hu, M., Zhang, Y., Andreae, M. O., and Pöschl, U.: Cloud condensation nuclei in polluted air and biomass burning smoke near the megacity Guangzhou, China - Part 2: Size-resolved aerosol chemical composition, diurnal cycles, and externally mixed weakly CCN-active soot particles, Atmos. Chem. Phys., 11, 2817-2836, https://doi.org/10.5194/acp-11-2817-2011, 2011.

Rosenfeld, D., Andreae, M. O., Asmi, A., Chin, M., de Leeuw, G., Donovan, D. P., Kahn, R., Kinne, S., Kivekäs, N., Kulmala, M., Lau, W., Schmidt, S., Suni, T., Wagner, T., Wild, M., and Quaas, J.: Global observations of aerosol-cloudprecipitation-climate interactions, Rev. Geophys., 52, 750-808, https://doi.org/10.1002/2013RG000441, 2014.

Schmale, J., Henning, S., Decesari, S., Henzing, B., Keskinen, H., Sellegri, K., Ovadnevaite, J., Pöhlker, M. L., Brito, J., Bougiatioti, A., Kristensson, A., Kalivitis, N., Stavroulas, I., Carbone, S., Jefferson, A., Park, M., Schlag, P., Iwamoto, Y., Aalto, P., Äijälä, M., Bukowiecki, N., Ehn, M., Frank, G., Fröhlich, R., Frumau, A., Herrmann, E., Herrmann, H., Holzinger, R., Kos, G., Kulmala, M., Mihalopoulos, N., Nenes, A., O'Dowd, C., Petäjä, T., Picard, D., Pöhlker, C., Pöschl, U., Poulain, L., Prévôt, A. S. H., Swietlicki, E., Andreae, M. O., Artaxo, P., Wiedensohler, A., Ogren, J., Matsuki, A., Yum, S. S., Stratmann, F., Baltensperger, U., and Gysel, M.: Long-term cloud condensation nuclei number concentration, particle number size distribution and chemical composition measurements at regionally representative observatories, Atmos. Chem. Phys., 18, 2853-2881, https://doi.org/10.5194/acp-18-2853-2018, 2018.

Snider, J. R. and Brenguier, J. L.: Cloud condensation nuclei and cloud droplet measurements during ACE-2, Tellus, 52B, 828842, 2000.

Ueda, S., Miura, K., Kawata, R., Furutani, H., Uematsu, M., Omori, Y., and Tanimoto, H.: Number-size distribution of aerosol particles and new particle formation events in tropical and subtropical Pacific Oceans, Atmos. Environ., 142, 324-339, 2016.

Wang, S. C. and Flagan, R. C.: Scanning electrical mobility spectrometer, Aerosol Sci. Tech., 13, 2230-2240, https://doi.org/10.1080/02786829008959441, 1990.

Yum, S. S., Roberts, G., Kim, J. H., Song, K., and Kim, D.: Submicron aerosol size distributions and cloud condensation nuclei concentrations measured at Gosan, Korea, during the Atmospheric Brown Clouds-East Asian Regional Experiment 2005, J. Geophys. Res., 112, D22S32, https://doi.org/10.1029/2006JD008212, 2007. 